



\section{Impact of fodder management on dairy farm performance in Kenya}

Asaah Ndambi ${ }^{1}$, Kevin Sinoya ${ }^{2}$, Boniface Sakwa ${ }^{3}$ and Jan van der Lee ${ }^{1}$

1 Wageningen Livestock Research, Wageningen University and Research, Netherlands

2 Department of Animal Production, University of Nairobi, Kenya

3 Department of Animal Sciences, Egerton University, Kenya

This research was conducted by Wageningen Livestock Research, commissioned and funded by the Embassy of the Kingdom of Netherlands in Kenya as part of the 3R Kenya project.

Wageningen Livestock Research

Wageningen, May 2020

3R Kenya Report 014

WLR Report 1250 
Asaah Ndambi, Kevin Sinoya, Boniface Sakwa and Jan van der Lee, 2020. Impact of fodder management on dairy farm performance in Kenya. 3R Kenya research report 014/Wageningen Livestock Research Report 1250.

\section{Summary}

This study assesses the impact of adoption of fodder conservation and feed rationing interventions on economic performance and nitrogen use efficiency (NUE) of dairy farms in central Kenya. A comparison was done between groups of farms in these intervention categories and with control farms that had no interventions. The results show that fodder conservation increased daily milk yield by 3 litres per lactating cow, while feed rationing in addition to fodder conservation gave an additional 3 litres milk per lactating cow per day in comparison to fodder conservation alone. We recommend farmers to adopt fodder conservation measures in combination with ration formulation in order to increase their profitability. Ration formulation advisory programs should include follow up visits to enable farm managers better understand formulation concepts, and potentially benefit from the effects of manure utilisation and soil mining for better estimates of NUE.

This report can be downloaded for free at https://doi.org/10.18174/521036, at www.wur.nl/livestock-research (under Wageningen Livestock Research publications), or at www.3r-kenya.org/dairy-publications/

\section{(C) 2020 Wageningen Livestock Research}

P.O. Box 338, 6700 AH Wageningen, The Netherlands, T +31 (0)317 4839 53, E info.livestockresearch@wur.nl, www.wur.nl/livestock-research. Wageningen Livestock Research is part of Wageningen University \& Research.

All rights reserved. No part of this publication may be reproduced and/or made public, whether by print, photocopy, microfilm or any other means, without the prior permission of the publisher or author.

Wageningen Livestock Research is NEN-EN-ISO 9001:2015 certified. All our research commissions are in line with the Terms and Conditions of the Animal Sciences Group. These are filed with the District Court of Zwolle.

Wageningen Livestock Research Report 1250, 3R Kenya Report 014 


\section{Table of contents}

$\begin{array}{ll}\text { Acknowledgements } & 5\end{array}$

$\begin{array}{ll}\text { Summary } & 7\end{array}$

$\begin{array}{llr}1 & \text { Introduction } & 9\end{array}$

$2 \quad$ Materials and methods $\quad 10$

$\begin{array}{lll}2.1 & \text { Area of study } & 10\end{array}$

$\begin{array}{lll}2.2 & \text { Categorization of farms and interventions } & 10\end{array}$

2.3 Farm selection $\quad 12$

2.4 Data collection and analysis $\quad 13$

2.4.1 Data collection 13

2.4.2 Statistical analysis 13

2.4.3 Nitrogen use efficiency assessment 14

$3 \quad$ Results and Discussion $\quad 15$

3.1 General description of prices and farm performance $\quad 15$

3.1.1 Milk prices $\quad 15$

$\begin{array}{ll}3.1 .2 \text { Feed prices } & 17\end{array}$

$\begin{array}{ll}3.1 .3 \text { Reproductive performance } & 18\end{array}$

3.2 Did fodder conservation (services) affect the performance of dairy farms? 19

3.3 Should fodder conservation be accompanied by ration formulation? 22

3.4 Should on-farm ration formulation trainings include regular (monthly) $\begin{array}{ll}\text { farm advisory visits? } & 24\end{array}$

3.5 Do conservation and ration formulation strategies affect seasonality in production? $\quad 25$

3.6 Do forage management interventions influence Nitrogen Use Efficiency of $\begin{array}{ll}\text { dairy farms? } & 26\end{array}$

Appendix 1 Feed ingredients and their nutritive value as used in NUE calculations $\quad 31$ 



\section{Acknowledgements}

This study was conducted as part of the $3 R$ project, funded by the Embassy of the Kingdom of Netherlands in Kenya (EKN). Undertaking this research project would not have been possible without support from a number of key persons. We thank all farm owners and managers for providing us with data from their farms. Our sincere gratitude to the support teams from SNV, and Perfometer, to Jos Creemers and Adolfo Alvarez for support in designing this study and training of enumerators. To Edith Wairimu and Elizabeth Okwach for support in data collection and analysis. We thank Şeyda Özkan Gülzari and Theun Vellinga for their inputs on the assessment of nitrogen use efficiency. Our appreciation to Patrick Irungu, Charles Gachuiri, James Ondiek, Catherine Kilelu and Simon Oosting for support in the research design and in reviewing of this report.

The authors 


\section{Summary}

The Kenyan dairy sector is threatened by high costs of production leading to low profitability among dairy to farmers. Feed costs have been estimated to account for $50-70 \%$ of production in dairy farms and is the greatest contributor to low farm profitability. As a country, Kenya has not fully maximized the potential of its dairy sector in terms of both nutrition and management. Knowledge on proper feeding and utilization of diverse feed resources in the country has not been well presented to majority of farmers. Shortages of feeds and high feed costs can be curbed by proper feed conservation and feed management strategies. To achieve this, some interventions were introduced in dairy farms by the Kenya Market-led Dairy Programme (KMDP), a project run by the Netherlands Development Organisation (SNV) and funded by the Embassy of the Kingdom of Netherlands in Kenya.

The objective of the study was to assess the economic impact and nitrogen use efficiency (NUE) of fodder-related interventions introduced by the KMDP on dairy farms in central Kenya. The farmers were classified into two major categories on the basis of the type of intervention introduced: fodder conservation and feed rationing. Those conserving fodder were further divided into two sub-categories; Service Provider Enterprise (SPE) comprised youth providing silage making services to small and medium scale farmers, and Maize Train (silage) comprised silage making services at larger scale and using more sophisticated machinery, mainly targeting medium and large scale farms. The feed rationing category comprised farms which, in addition to fodder conservation, practiced feed rationing. This category was also divided into two subcategories; one comprising farms practicing feed rationing without regular farm visits and the other group comprising farms practicing feed rationing using a software (Rumen8) with monthly farm advisory visits. These categories were compared with each other and with control farms which comprised farms from the same geographical location, having a similar production system but not practicing the interventions.

The results show that farms practicing fodder conservation had a higher milk yield and higher income per cow than control farms. Farms practicing fodder conservation obtained 3 litres more milk per lactating cow per day on average compared to the control group. A similar difference of 3 litres per lactating cow per day was observed when comparing farms practicing feed rationing in addition to fodder conservation, compared with those only doing fodder conservation.

Farms formulating their own feeds using the Rumen 8 software combined with monthly farm advisory visits had a higher productivity and better economic performance than those practicing formulation without monthly advisory visits. In terms of the NUE, the differences between interventions were small and it is recommended that for better NUE assessment of dairy farms, further investigation of the manure management practices would be required.

In conclusion, practicing fodder conservation increased the profitability of the dairy enterprise. We recommend that farmers adopt fodder conservation measures in combination with ration formulation in order to increase their profitability. Ration formulation advisory programs should include follow up visits for a longer duration to enable farm managers to better understand the concepts involved in formulation, and could potentially benefit from incorporating the effects of manure utilisation and soil mining for better estimates of NUE. 


\section{Introduction}

Kenya's dairy industry is among the largest in sub-Saharan Africa. The sector plays a significant role in the nutrition of citizens through milk and its processed products, provides manure for soil fertilization, serves as a cash reserve to farmers, creates of employment and generates income to many people (Olwande et al., 2015). Kenya's average per capita milk consumption of $110 \mathrm{~kg}$ is one of the highest in sub-Saharan Africa (Rademaker et al., 2016). The Kenyan dairy sector contributes about $4 \%$ to the national gross domestic product (GDP) and milk production is growing at an average rate of $5.3 \%$ per year while milk processing and consumption are also expanding (MoALF, 2010).

The Kenyan dairy sector is threatened by the high cost of production leading to low profitability the dairy enterprise (Ndambi et al., 2017). Feed accounts for $50-70 \%$ of total cost in dairy farms and is the greatest contributor to low farm profitability (Alqaisi et al., 2014). Strategies to improve farm profitability should therefore focus on improving feed utilization efficiency so as to reduce feed costs per unit of output. Improving the feed utilisation efficiency through high quality forages and alternative feeding practices has the potential to increase farmers' income, in addition to yielding positive effects on the environment through the use of nitrogen. However, the high seasonality in feed availability is a key threat to milk production in Kenya (Njarui et al., 2016).

Globally, livestock production contributes about $15 \%$ of the total anthropogenic greenhouse gas (GHG) emissions of which ruminants are responsible for about $40 \%$ from the production of enteric methane (Gerber et al. 2013). Methane release entails an energy loss from the cow's and if reduced through better feeding, it can be re-gained in animal products, leading to improved production efficiency and profitability (Eckard et al., 2010).

There have been some interventions by the Dutch-funded Kenya Market-led Dairy Programme (KMDP) project implemented by SNV Kenya, aiming at improving year-round fodder availability and ration formulation by dairy farmers in Kenya. The project involved two interventions on fodder conservation through silage making (Service Provider Enterprises (SPE) and maize train silage) and two interventions on feed rationing (one without and one with monthly farm advisory visits) have shown good potential to foster business relationships with international suppliers of equipment and know-how in the field of forage production and conservation. In order to identify the best fodder strategies for medium and small-scale farms, the impact of each of these innovations on farm profitability was assessed to determine the extent to which their adoption affects GHG emissions. The objective of this study was therefore to assess the impact of KMDP fodder-related interventions on the profitability and nitrogen use efficiency of dairy farms in Kenya.

This study attempted to answer to following research questions:

1. Did fodder conservation and/or the use of fodder conservation services affect the economic performance of dairy farms in comparison to similar farms within the same geographical area?

2. Is it sufficient to train Kenyan farmers on fodder conservation only or to support them in ration formulation?

3. If farmers are trained on ration formulation, is it sufficient and cost-effective to train them once or to train them regularly (monthly)?

4. To what extent were the farms that participated in study interventions affected by seasonality of fodder availability?

5. To what extent do forage management interventions influence the Nitrogen Use Efficiency (NUE) in dairy farms? 


\section{$2 \quad$ Materials and methods}

\section{$2.1 \quad$ Area of study}

The data were collected from eleven counties in central, eastern and rift valley regions of Kenya namely in Kajiado, Kiambu, Kirinyaga, Machakos, Meru, Muranga, Nakuru, Nyandarua, Nyeri, Trans Nzoia, and Uasin Gishu. These counties were selected on the basis of their high milk production and they had also hosted the KMDP fodder innovations project.

\subsection{Categorization of farms and interventions}

The KMDP innovations on fodder were categorized into two main intervention groups (Figure 1). These were fodder conservation and feed rationing. The fodder conservation category was further divided into two groups, i.e., Service Provider Enterprise (SPE) mainly targeting smallholder farmers, and maize train/baler mainly targeting medium and large scale farmers. The feed rationing category was also divided into two groups; i.e., rationing without regular farm advisory visits and feed rationing using RUMEN8 (R8) tool, including monthly farm advisory visits.

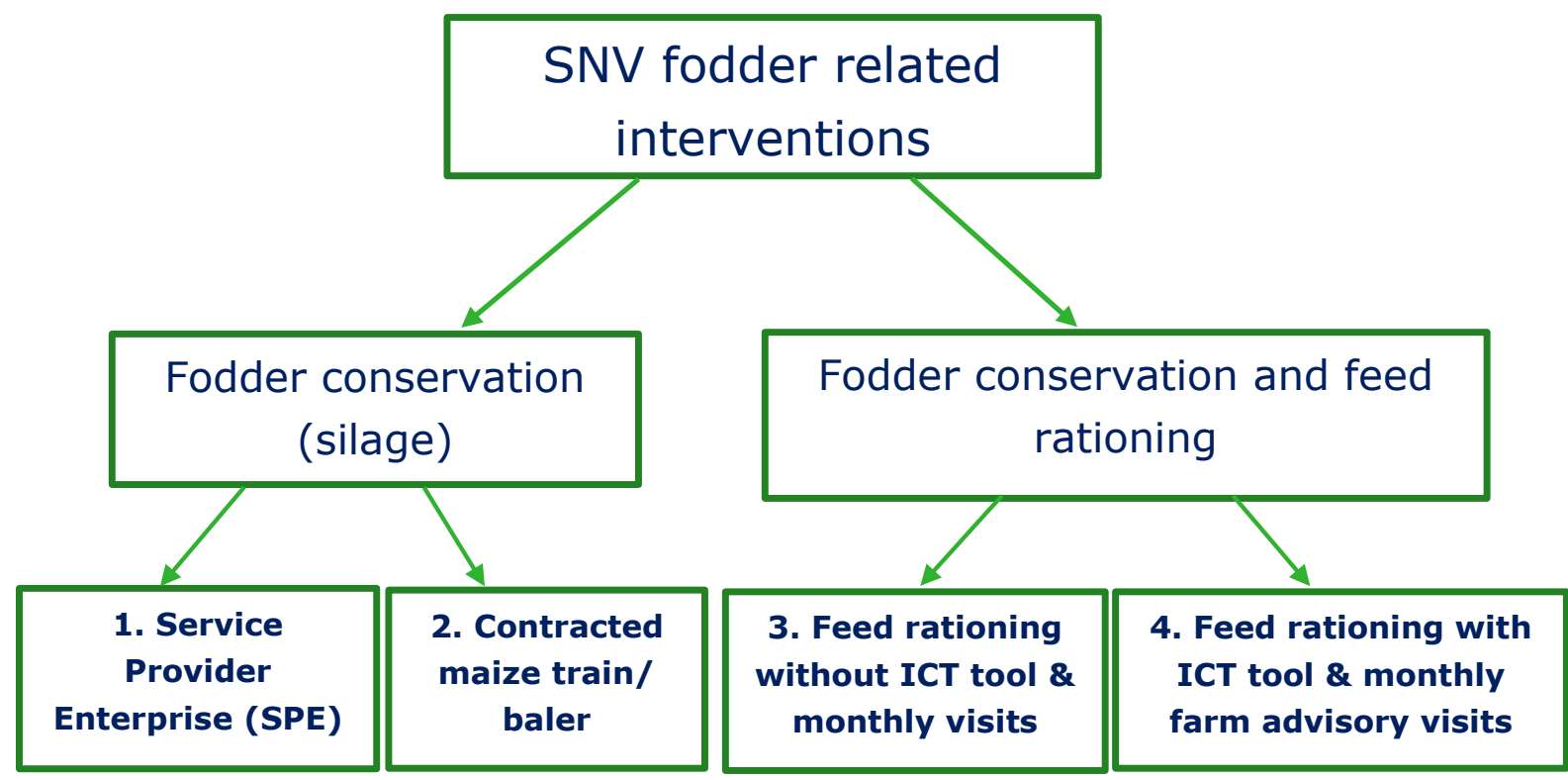

Figure 1 Categorization of KMDP fodder interventions in dairy farms in Kenya.

i) Service Provider Enterprise services

The SPE is a youth-led business model where youth form groups to offer commercial support services to smallholders and medium-scale farmers in the dairy value chain. Their main service includes silage making. However, they also support farmers with other services such as biogas installation, fodder establishment, supply of inputs, farmer training and advisory services, construction of zero-grazing units and soil testing (Kilelu et al., 2017) as shown in Plate 1. 

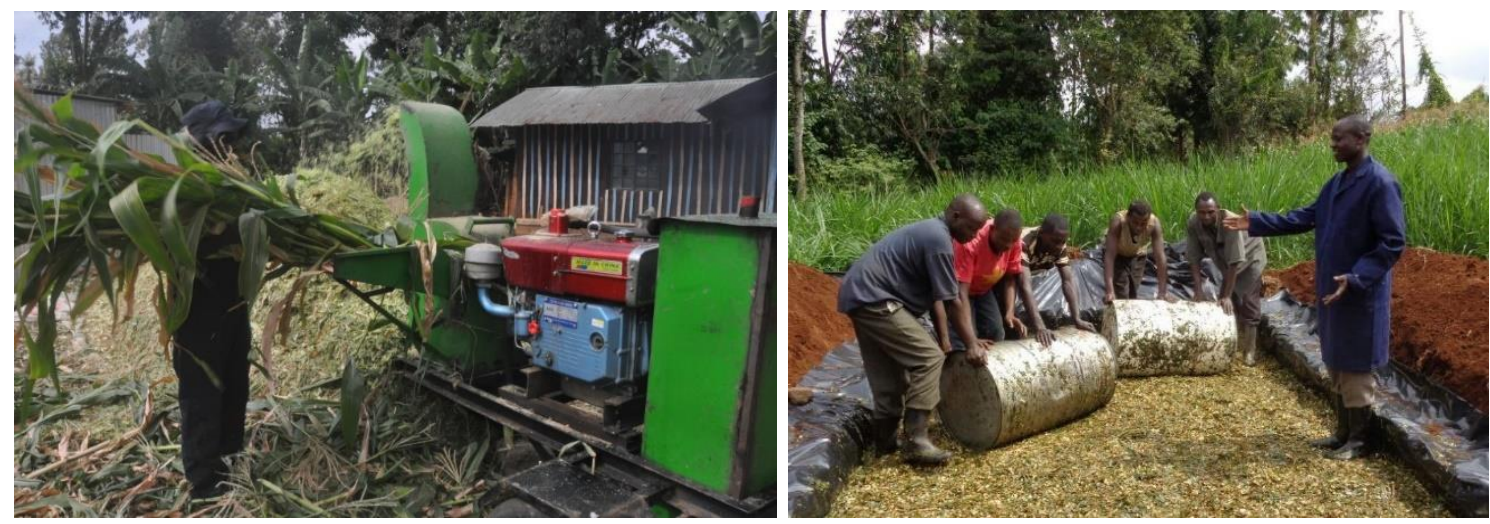

Plate 1 Fodder chopping and silage making using the SPE model in dairy farms in Kenya.

ii) Medium-to-large scale maize train/baled silage

This group consisted of medium and large-scale farmers who own and/or use large machinery in silage cultivation and preparation. Nundoroto is an agricultural contracting company in Uasin Gishu which is one of the early investors into this innovation and is providing silage to several medium and large farms within its environs. The company is equipped with tractors, ploughs, seeders, a forage maize harvester, loaders and a shovel for silage compaction. In 2018, baling of silage was introduced in Kenya and some of these farms produce large bales of silage for sale to medium and large-scale farms (see Plate 2 ).
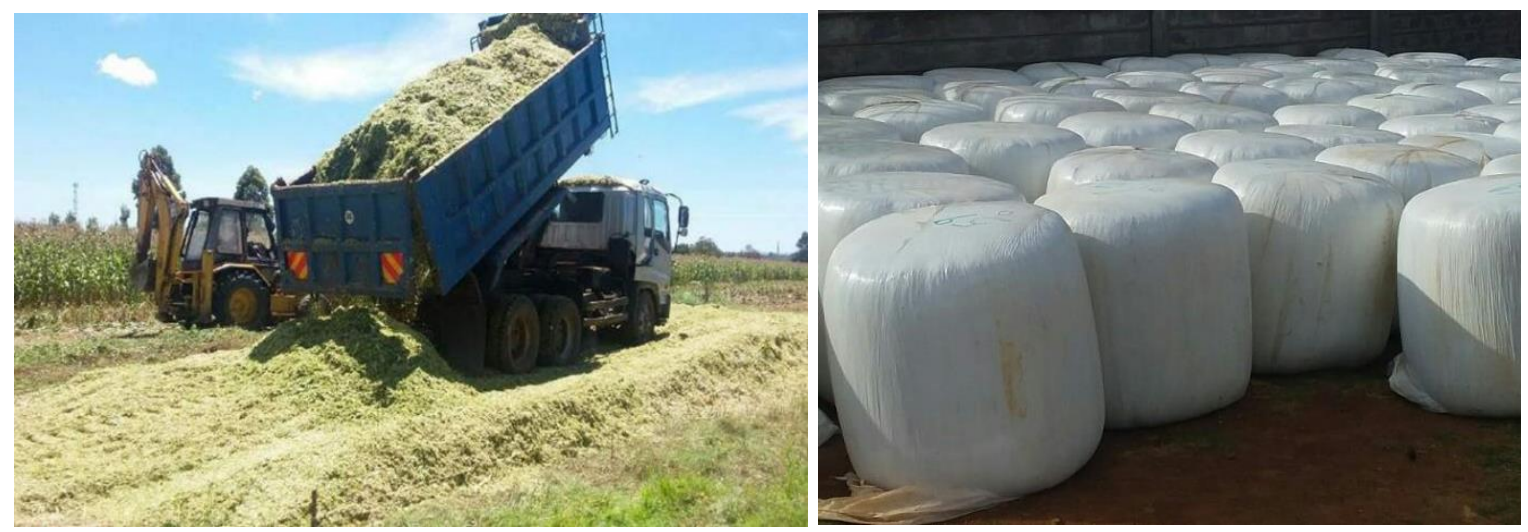

Plate 2 Silage making in maize train dairy farms in Kenya.

iii) Ration formulation without regular expert visits

Farmers of this group were trained on feed rationing at least once and have a feed plan, but do not get monthly follow up visits by KMDP experts. These farmers also use maize silage in their rations (see Plate 3 ). 


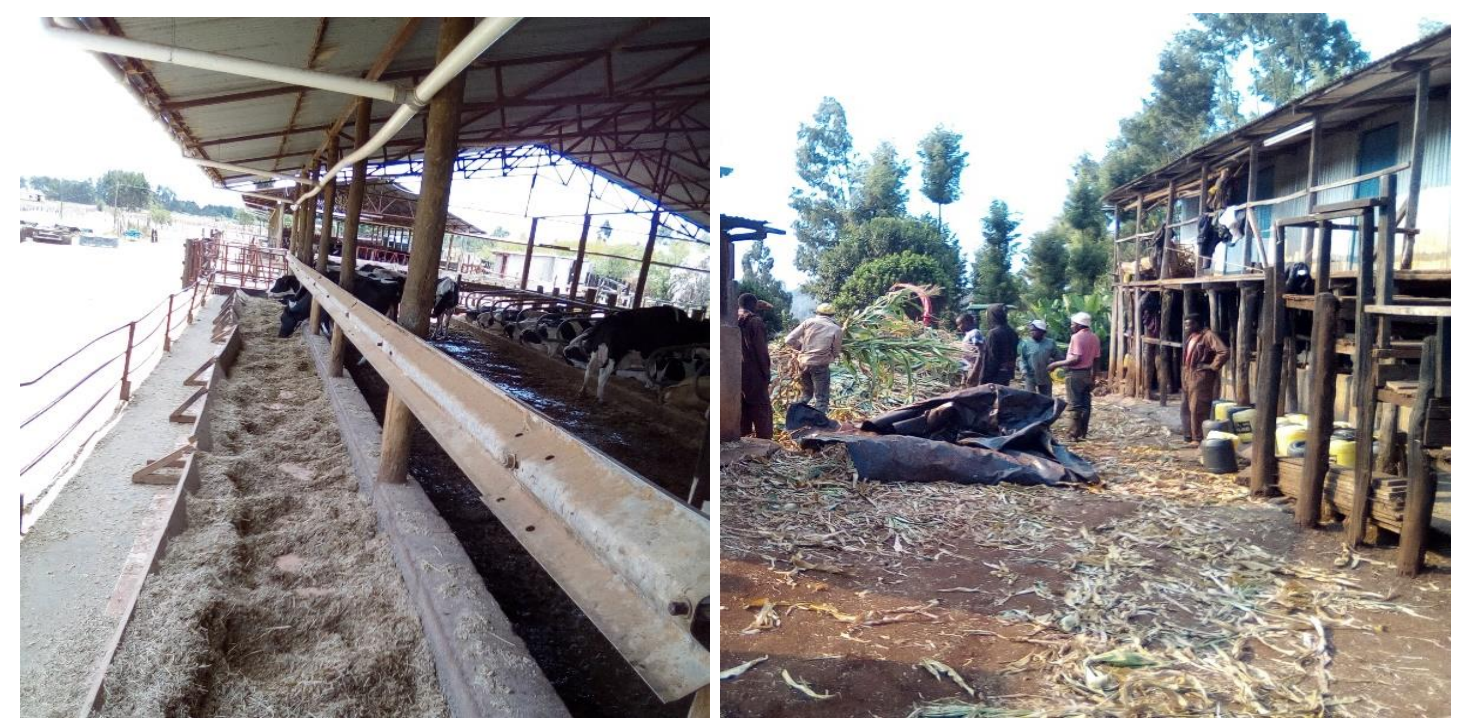

Plate $3 \quad$ Feeding and grass and preparing silage on farms with own ration formulation plan.

iv) Ration formulation with support of the Rumen8 software and monthly farm visits

Feed rationing for farmers in this group was done by animal nutrition experts who visited the farms monthly and recalculated a suitable diet for the cows based on the stage of lactation of the cows and the available feeds. Farmers also got advice on fodder cultivation and general herd management (see Plate 4).
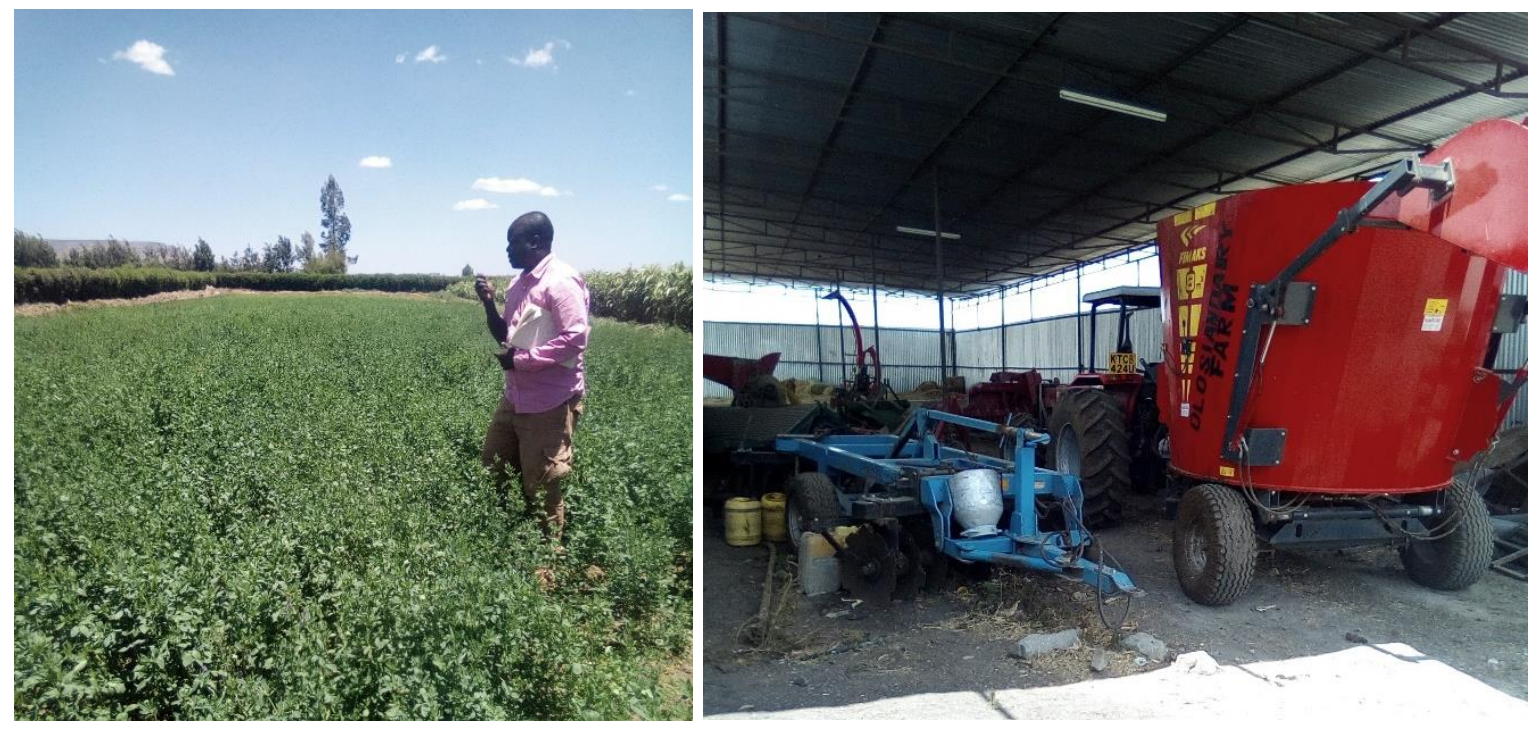

Plate 4 Monitoring of Lucerne and b) farm equipment on a farm with Rumen8 ration balancing.

\subsection{Farm selection}

The first step of farm selection was a mapping of key areas of intervention for the KMDP feed innovations described above. A typology of farms with access to these interventions was done using contact lists provided by KMDP. Farms were classified based on the interventions they adopted (Figure 1). Two control groups were made for SPE and Maize train interventions respectively, making a total of six study groups. The control groups comprised farmers from the same geographical area in the same farming system and having a similar scale of production but who did not access either the fodder intervention or farm advisory services from KMDP. At least 11 farms were analysed per group, from all six (intervention and control) groups; and a total of 77 farms for the study. 
It should be noted that SPE and maize train innovations were mutually exclusive because adopters could only use silage services from one of the providers in the same farming season based on their scale of production. Additionally, ration balancing innovations (with or without advice) were mutually exclusive because it was only possible to belong to one group at a time. However, farmers practicing ration balancing were also conserving or using conserved fodder, hence, the ration balancing interventions was an addition to fodder conservation.

\subsection{Data collection and analysis}

\subsubsection{Data collection}

Dairy input and output data were collected using the android-operated Open Data Kit (ODK) in two questionnaires:

i) Questionnaire 1 collected monthly data on feeding, herd dynamics, milk and feed prices etc. for six months (February to July 2019). In the first five months, this was done for all interventions excluding the control groups. In the last month (July), control farms were included for the intervention groups with fodder conservation and the same data collected. It should be noted that the research design was adjusted during the data collection phase. Initially, there was only one control group for all interventions. Due to an identified weakness in showing the actual effect of each intervention, the design was changed to include control groups for each fodder conservation intervention.

ii) Questionnaire 2 collected one-time data on use of farm inputs like fertilizer, pesticides, etc. and also limited data on manure management. Data on inputs, in addition to the monthly data collected in Questionnaire 1 were used for assessing the NUE.

\subsubsection{Statistical analysis}

Farm profitability was calculated for different adopters using Rumen8 and SPSS software. The prices for milk and various feed ingredients were analysed and compared as these were considered the main drivers of farm profitability. The following approaches were used to answer the research questions:

i. Did fodder conservation and/or the use of fodder conservation services affect the economic performance of dairy farms in comparison to their control?

Mean values for reproductive performance indicators (age at first calving, calving interval, etc.) were calculated and compared for fodder conservation groups and their control. An independent sample T-test was also conducted to compare the means of intervention groups and their controls based on their milk yield, milk production and milk income.

ii. Is it sufficient to train Kenyan farmers on fodder conservation only or to support them in ration formulation?

To answer this question, the farmers were split into three groups and compared: those with no intervention ( $n=22)$, those that were only trained on fodder conservation $(n=$ 24 ), and those that were trained on both fodder conservation and ration formulation ( $n$ $=31$ ). A one-way ANOVA test was used to compare the means of these three groups on their milk yield, milk production and milk income.

iii. If farmers are trained on ration formulation, is it sufficient and cost-effective to train them once or to train them regularly (monthly)?

In order to respond to this question, farms from the two groups rationing without visit and rationing \& visit were compared. The Rumen 8 tool was used to calculate and compare their milk yield, feed cost, margin above feed cost. In addition, SPSS was used to calculate the milk income per litre, hours spent per cow per day, milk produced per 
hour, and percentage of dry cows in herd in order to compare the herd performance of the two groups.

iv. To what extent were farms that participated in interventions affected by seasonality in fodder production/availability?

Here, the milk yield per cow per day and total milk per farm per day were compared monthly for the various interventions over duration of six months. A trendline analysis of milk production $(Y)$ over months $(X)$ was conducted to see the effect of seasonality on milk yield.

v. To what extent do forage management interventions influence the Nitrogen Use Efficiency (NUE) of dairy farms? The approach is explained in the next paragraph.

\subsubsection{Nitrogen use efficiency assessment}

The $\mathrm{N}$ flow was computed at farm gate level as described by Brouwer (1998), reflecting the quantification of $\mathrm{N}$ entering the farm (e.g. concentrates, roughage, etc) and the $\mathrm{N}$ leaving the farm. Live animals sold or purchased, imported or exported synthetic and organic fertilisers as well as any exported feed were excluded due mainly to the low use of fertilisers in a many of the study farms, but with an expected variation between interventions. The quantity of $\mathrm{N}$-input from feed was calculated by multiplying the amount of each feed (DMI) by its CP content (Appendix 1) and dividing it by a factor of 6.25 (intake of $N$ ), which accounts for the $16 \% \mathrm{~N}$ in proteins (AOAC, 1995). Nitrogen output in milk was calculated by dividing the amount of milk protein ( $\mathrm{kg} / \mathrm{farm})$ by its nutrient content (6.38 for milk solids) (SCA 1990, p. 79). Nitrogen use efficiency (NUE) was calculated according, and with modifications, to Dalgaard et al. (1998) as N in milk / $\mathrm{N}$ in feed ingredients, and was expressed in \% per cow. Percentages refer to the $\mathrm{N}$ transfer from one part to another. As can be seen in Figure 2, about $5-45 \%$ of $\mathrm{N}$ intake is usually retained in animal products while the rest is excreted in urine and faeces (Oenema and Tomminan onnci

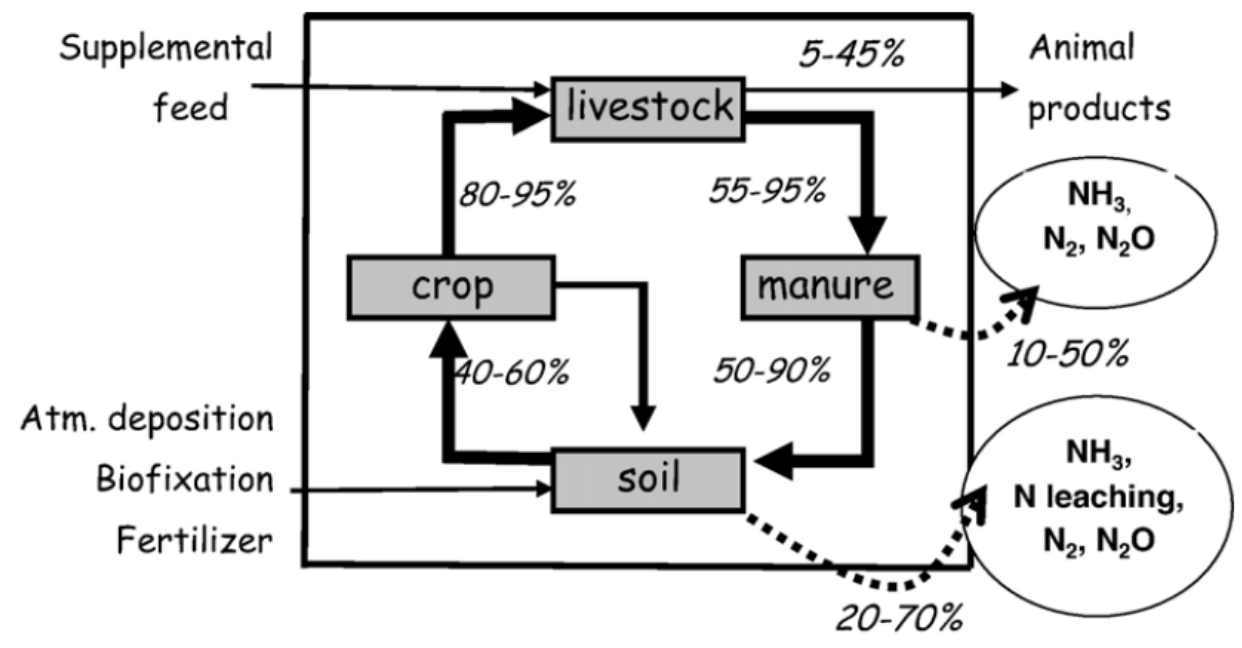

Figure 2 Nitrogen flows in a livestock farm showing livestock, manure, soil and crop.

(Source: Oenema and Tamminga, 2005)

NUE provides useful information in raising awareness at farm, advisory and policy levels (Gerber et al., 2014). As a key indicator, NUE can inform farmers on the extent to which they convert $N$ inputs to $\mathrm{N}$ outputs (Godinot et al., 2014). This analysis, therefore, investigates investigated the overall conversion of inputs to outputs, using NUE as a proxy in dairy farms adapting different feed management practices in Kenya. However, it should be noted that the effect of manure collection and utilisation on the field, and the effect of soil mining on NUE efficiency is not assessed in this study. 


\section{Results and Discussion}

This section starts with a general description of prices of milk and various feed ingredients used in the study farms, as these could affect farm profitability. Reproductive performance indicators are also presented as an average for all farms to give a general picture of farm management. The results further elaborate responses to the research questions; if:

1. Fodder conservation (services) affect the performance of dairy farms.

2. Support on fodder conservation should be accompanied by support in ration formulation.

3. Ration formulation training should be accompanied by monthly advisory visits.

4. Conservation and rationing are affected by the seasonality in production of dairy farms.

5. Forage management interventions influence the environmental footprints of dairy farms.

\subsection{General description of prices and farm performance}

This section looks at the average prices of milk and feed in all farms analysed, as well as reproductive performance of these farms.

\subsubsection{Milk prices}

The milk prices varied based on the market outlets where farmers sold their milk (Figure 3 ). Farmers selling milk to the dairy cooperative received the lowest price of 32.3 KES per litre of milk, which was only $60 \%$ of the milk price if farmers owned a milk bar ( $55.6 \mathrm{KES}$ per litre) (Staal et al., 2003). Farmers delivering directly to processors received an average of 3 KES more than those delivering milk through cooperatives. Selling to schools and hotels which were closely connected to the end consumers was also an attractive option for farmers.

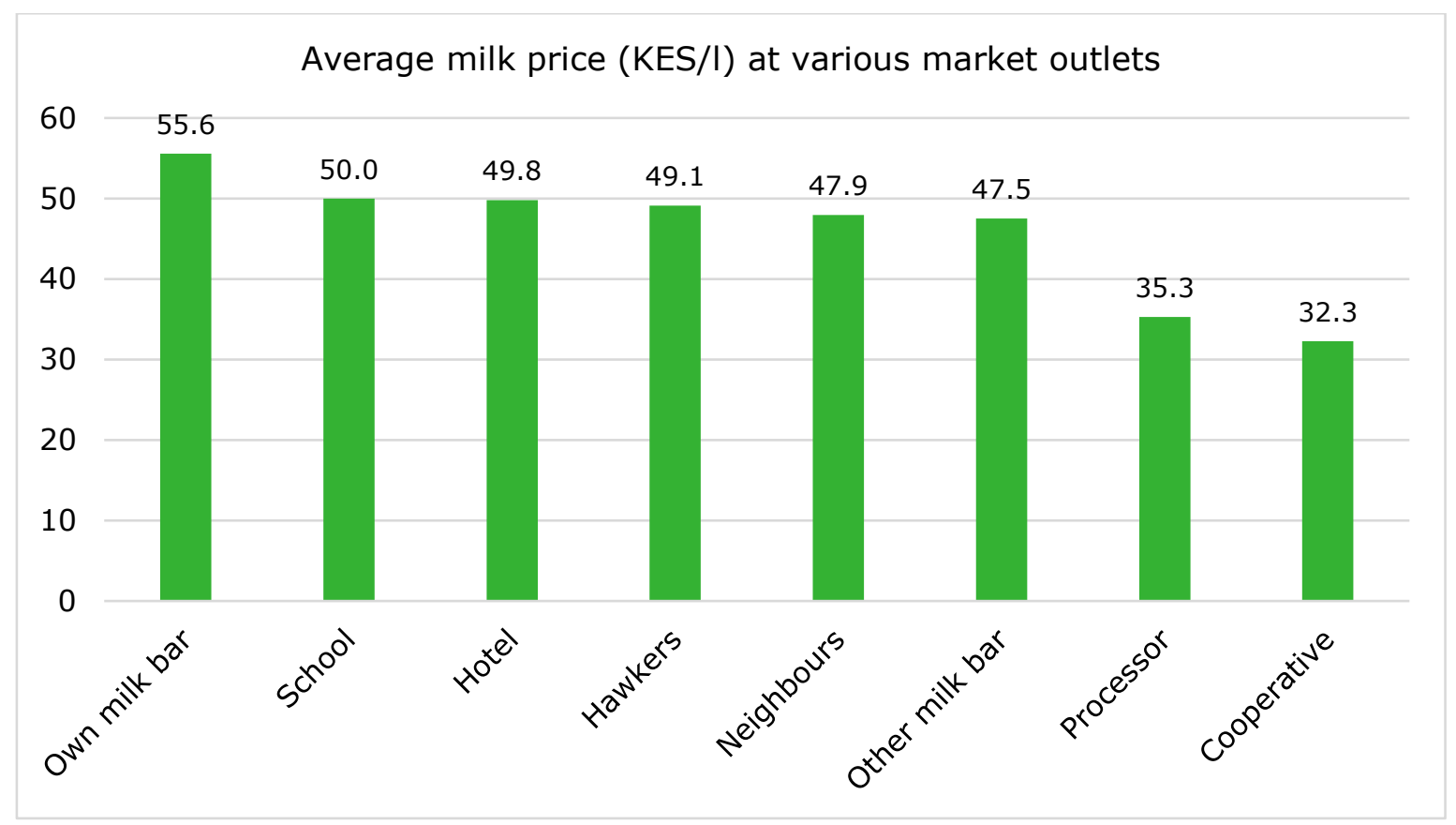

Figure 3 Average milk prices obtained at various outlets by dairy farmers in the study. 
Table 1 Breakdown of milk prices at various market outlets by intervention.

\begin{tabular}{|c|c|c|c|c|c|c|c|c|c|c|}
\hline & & Coope- & Hawkers & & Other & Hotels & Schools & Neigh- & Proces- & Others \\
\hline & & rative & & milk bar & milk bar & & & bours & sors & \\
\hline \multirow[t]{2}{*}{ SPE Control } & $\%$ of farmers selling to: & $45 \%$ & $9 \%$ & $0 \%$ & $0 \%$ & $0 \%$ & $9 \%$ & $55 \%$ & $9 \%$ & $18 \%$ \\
\hline & Average milk price at: & 31.2 & 38.0 & - & - & - & 50.0 & 46.7 & 35.0 & 35.0 \\
\hline \multirow[t]{2}{*}{ SPE } & $\%$ of farmers selling to: & $42 \%$ & $0 \%$ & $17 \%$ & $0 \%$ & $8 \%$ & $25 \%$ & $58 \%$ & $33 \%$ & $8 \%$ \\
\hline & Average milk price at: & 32.4 & - & 55.0 & - & 55.0 & 46.7 & 47.9 & 33.5 & - \\
\hline \multirow{2}{*}{$\begin{array}{l}\text { Maize train } \\
\text { control }\end{array}$} & $\%$ of farmers selling to: & $18 \%$ & $64 \%$ & $0 \%$ & $0 \%$ & $18 \%$ & $9 \%$ & $0 \%$ & $18 \%$ & $0 \%$ \\
\hline & Average milk price at: & 31.0 & 50.0 & - & - & 50.0 & 50.0 & - & 32.0 & - \\
\hline \multirow[t]{2}{*}{ Maize train } & $\%$ of farmers selling to: & $33 \%$ & $58 \%$ & $0 \%$ & $0 \%$ & $17 \%$ & $0 \%$ & $0 \%$ & $25 \%$ & $0 \%$ \\
\hline & Average milk price at: & 31.5 & 50.0 & - & - & 50.0 & - & - & 32.0 & - \\
\hline \multirow{2}{*}{$\begin{array}{l}\text { Rationing without } \\
\text { visits }\end{array}$} & $\%$ of farmers selling to: & $33 \%$ & $11 \%$ & $11 \%$ & $6 \%$ & $17 \%$ & $0 \%$ & $11 \%$ & $22 \%$ & $11 \%$ \\
\hline & Average milk price at: & 32.2 & 50.0 & 50.0 & 50.0 & 47.7 & - & 47.5 & 40.0 & 47.5 \\
\hline \multirow{2}{*}{$\begin{array}{l}\text { Rationing with } \\
\text { farm advisory } \\
\text { visits }\end{array}$} & $\%$ of farmers selling to: & $17 \%$ & $11 \%$ & $28 \%$ & $6 \%$ & $6 \%$ & $6 \%$ & $11 \%$ & $33 \%$ & $22 \%$ \\
\hline & Average milk price at: & 36.0 & 47.5 & 58.0 & 45.0 & 50.0 & 60.0 & 52.5 & 36.2 & 76.3 \\
\hline
\end{tabular}

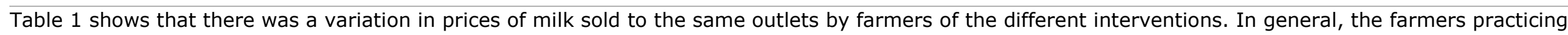

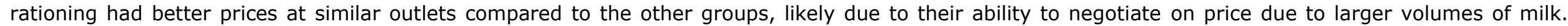
A larger proportion of the smallholder farmers (SPE and SPE control groups) sold milk to their neighbours compared to the other groups. 


\subsubsection{Feed prices}

Table 2 Average (and standard deviation) of farm gate prices in (KES/ $\mathrm{kg}$ ) for the most common feed ingredients used based on study groups.

\begin{tabular}{|c|c|c|c|c|c|c|}
\hline \multirow{2}{*}{$\begin{array}{l}\text { Feed } \\
\text { ingredient }\end{array}$} & \multicolumn{6}{|c|}{ Study groups } \\
\hline & $\begin{array}{c}\text { SPE } \\
\text { control }\end{array}$ & SPE & $\begin{array}{c}\text { Maize } \\
\text { train } \\
\text { control }\end{array}$ & Maize train & $\begin{array}{c}\text { Rationing } \\
\text { without } \\
\text { visits }\end{array}$ & $\begin{array}{l}\text { Rationing } \\
\text { \& farm } \\
\text { advisory } \\
\text { visits }\end{array}$ \\
\hline $\begin{array}{l}\text { Fresh cut } \\
\text { grass }\end{array}$ & $\begin{array}{c}2.0 \\
(0.00)\end{array}$ & $\begin{array}{c}2.0 \\
(0.30)\end{array}$ & $\begin{array}{c}2.1 \\
(1.32)\end{array}$ & $\begin{array}{c}1.1 \\
(0.25)\end{array}$ & $\begin{array}{c}2.3 \\
(1.03)\end{array}$ & $\begin{array}{c}2.1 \\
(0.57)\end{array}$ \\
\hline Barley straw & & & & & $\begin{array}{c}11.0 \\
(7.07)\end{array}$ & \\
\hline Rice straw & & & & & $\begin{array}{c}8.0 \\
(0.00)\end{array}$ & \\
\hline Wheat straw & & & & $\begin{array}{c}3.7 \\
(1.15)\end{array}$ & & $\begin{array}{c}3.5 \\
(2.12)\end{array}$ \\
\hline Maize stover & $\begin{array}{c}0.5 \\
(0.00)\end{array}$ & $\begin{array}{c}0.7 \\
(0.29)\end{array}$ & $\begin{array}{c}1.5 \\
(0.00)\end{array}$ & & $\begin{array}{c}2.3 \\
(0.00)\end{array}$ & \\
\hline Grass silage & & $\begin{array}{c}3.0 \\
(0.52)\end{array}$ & & & & $\begin{array}{c}4.6 \\
(0.55)\end{array}$ \\
\hline Maize silage & & $\begin{array}{c}6.2 \\
(1.59)\end{array}$ & $\begin{array}{c}9.6 \\
(2.26)\end{array}$ & $\begin{array}{c}7.1 \\
(1.75)\end{array}$ & $\begin{array}{c}9.0 \\
(1.58)\end{array}$ & $\begin{array}{c}7.8 \\
(2.65)\end{array}$ \\
\hline Hay & & $\begin{array}{c}13.7 \\
(1.89)\end{array}$ & $\begin{array}{c}13.6 \\
(3.44)\end{array}$ & $\begin{array}{c}9.1 \\
(4.20)\end{array}$ & $\begin{array}{c}12.8 \\
(5.47)\end{array}$ & $\begin{array}{c}12.6 \\
(4.85)\end{array}$ \\
\hline Molasses & & $\begin{array}{c}33.3 \\
(0.00)\end{array}$ & & & $\begin{array}{c}26.3 \\
(8.84)\end{array}$ & $\begin{array}{c}24.4 \\
(6.92)\end{array}$ \\
\hline Wheat Bran & & $\begin{array}{c}14.0 \\
(6.69)\end{array}$ & & & $\begin{array}{c}14.3 \\
(0.52)\end{array}$ & $\begin{array}{c}15 \\
(0.00)\end{array}$ \\
\hline Maize grain & & $\begin{array}{c}32.0 \\
(0.00)\end{array}$ & & & & \\
\hline Maize germ & & $\begin{array}{c}30.0 \\
(0.00)\end{array}$ & & & $\begin{array}{c}25.7 \\
(2.58)\end{array}$ & \\
\hline Soybean meal & & & & & $\begin{array}{c}74.5 \\
(19.6)\end{array}$ & \\
\hline Brewer's grain & & & & & $\begin{array}{c}6.0 \\
(3.16)\end{array}$ & \\
\hline $\begin{array}{l}\text { Commercial } \\
\text { dairy } \\
\text { concentrate }\end{array}$ & $\begin{array}{l}25.48 \\
(0.57)\end{array}$ & $\begin{array}{c}31.1 \\
(3.46)\end{array}$ & $\begin{array}{c}27.9 \\
(5.57)\end{array}$ & $\begin{array}{c}30.3 \\
(5.07)\end{array}$ & $\begin{array}{c}28.7 \\
(5.00)\end{array}$ & $\begin{array}{c}27.2 \\
(5.43)\end{array}$ \\
\hline Minerals & $\begin{array}{c}128.3 \\
(33.57)\end{array}$ & $\begin{array}{c}158.4 \\
(18.43)\end{array}$ & & & $\begin{array}{c}142.2 \\
(21.30)\end{array}$ & $\begin{array}{c}156 \\
(24.82)\end{array}$ \\
\hline
\end{tabular}


Table 2 shows the mean and standard deviation of prices of various feed ingredients in the various study groups. Few of farmers in the groups used and provided feed prices for straws, grass silage, maize grain, maize germ, soybean meal and brewer's grain, while fresh cut grass, maize silage, hay and commercial dairy concentrate were more commonly purchased by farmers in (almost) all of the groups. The blank spaces in the Table do not necessarily mean that farmers did not use the feed ingredient. Some farmers did not provide feed prices. There was a small variation in the price per $\mathrm{kg}$ of similar feed items between the farms, except for maize stover where the highest average value was more than two times the lowest. Though the price for fresh grass (mainly Napier) was similar across groups, there is often a difference in its quality depending on the stage when it is cut. Bought grass is usually left to grow taller in order to get more biomass, but its protein value decreases when it ages (Snijders et al., 2011). For minerals, the variation was mainly because of differences in the kind of mineral and brands that farmers bought. Differences in maize silage price were driven by different forms of contractual agreements for silage making. Some farmers bought whole maize plants and produced silage on their farms, some hired machinery to silage from their home-grown fodder, others purchased ready-made silage in small bales (about $60 \mathrm{~kg}$ ) or large bales (about $350 \mathrm{~kg}$ ). With these differences, it is evident that better feed planning can further reduce the feed cost. The differences between prices in this table were not tested statistically.

\subsubsection{Reproductive performance}

The age at first calving, calving interval, lactation length and duration of the dry period for all farms are shown in Table 3.

Table 3 Reproductive performance of dairy cows in the study farms.

\begin{tabular}{|c|c|c|c|c|c|c|c|c|c|}
\hline \multicolumn{6}{|c|}{ All farms } & \multicolumn{4}{|c|}{ Average per intervention } \\
\hline & $\mathbf{n}$ & Mean & $\begin{array}{l}\text { Stand- } \\
\text { ard } \\
\text { devia- } \\
\text { tion }\end{array}$ & $\begin{array}{l}\text { Mini- } \\
\text { mum }\end{array}$ & $\begin{array}{l}\text { Maxi- } \\
\text { mum }\end{array}$ & SPE & $\begin{array}{l}\text { Maize } \\
\text { train }\end{array}$ & $\begin{array}{c}\text { Rationing } \\
\text { without } \\
\text { visits }\end{array}$ & $\begin{array}{c}\text { Rationing } \\
\text { with farm } \\
\text { advisory } \\
\text { visits }\end{array}$ \\
\hline $\begin{array}{l}\text { Age at first } \\
\text { calving } \\
\text { (months) }\end{array}$ & 63 & 27.0 & 4.1 & 24.0 & 48.0 & 32.1 & 25.4 & 25.5 & 26.4 \\
\hline $\begin{array}{l}\text { Calving } \\
\text { interval } \\
\text { (days) }^{\infty}\end{array}$ & 61 & 420 & 100 & 360 & 780 & 520 & 405 & 400 & 405 \\
\hline $\begin{array}{l}\text { Lactation } \\
\text { length (days) }\end{array}$ & 57 & 320 & 37 & 218 & 450 & 354 & 302 & 313 & 329 \\
\hline $\begin{array}{l}\text { Dry period } \\
\text { (days)* }\end{array}$ & & 100 & & & & 166 & 103 & 87 & 76 \\
\hline $\begin{array}{l}\text { Weaning age } \\
\text { (months) }\end{array}$ & 62 & 3.10 & 0.30 & 3.00 & 4.00 & 3.18 & 3.07 & 3.10 & 3.07 \\
\hline
\end{tabular}

* Dry period was calculated as the difference between calving interval and lactation length

Table 3 shows that, when looking at all farms, there was a wide variation between the minimum and maximum values for the considered reproduction parameters. It should be noted that these values were based on data provided by farmers, with a majority of them not keeping such records and depending on their memory. The average age at first calving for the group with rationing and advisory visits of 26.4 was about 2 months lower that that obtained by Braamhaar (2019) who reported an average age at first calving of 28.5 months. The same study (Braamhaar, 2019) found an average calving interval of 455 days for the group with rationing 
and advisory visits, compared to 405 days in this study. These differences could arise from improvements due to longer use of farm advice, or due to the challenges in record keeping and availability of herd management data. The table shows that SPE farms had a higher mean value for age at first calving and longer calving interval than the other groups, probably due to better management in the other groups, which had more cows per farm. Long calving intervals and lactation periods are associated with interrupted breeding, poor feeding, fertility problems, poor management, delayed inseminations due to high costs or inaccessible AI services etc. (Mungube et al., 2019). Delayed first calving and long calving intervals result in increased costs of rearing and decreased lifetime milk production and number of calvings (Watanabe et al., 2017). Management of the animals and general nutrition plays a major role in determining age at first service of the heifers. Most of the farmers in the SPE group, unlike in the other interventions, concentrated on the lactating cows and invested less in the heifers which most likely led to the high age at first calving. A low age at first calving requires proper heifer management maximizing growth rates to ensure the right body weight and frame size at service (Haworth et al., 2008).

\subsection{Did fodder conservation (services) affect the performance of dairy farms?}

To answer this question, farms adopting different interventions were compared with their controls for the following variables: milk income, milk yield per cow per day, feed costs and margin above feed costs (MAFC).

Prior to answering the research questions, it was necessary to understand the general characteristics of the farms from the intervention groups as shown in Table 3.

Table 4 Mean number and (proportion) of farms per intervention category.

\begin{tabular}{|c|c|c|c|c|c|c|c|c|}
\hline \multicolumn{3}{|c|}{ Herd size } & \multicolumn{3}{|c|}{$\begin{array}{l}\text { Farm size categories } \\
\text { (liters/farm/day) }\end{array}$} & \multicolumn{3}{|c|}{$\begin{array}{l}\text { Farm production } \\
\text { system }\end{array}$} \\
\hline $\begin{array}{l}\text { Farm } \\
\text { categor } \\
\text { ies }\end{array}$ & $\begin{array}{l}\text { No. of } \\
\text { farms }\end{array}$ & $\begin{array}{l}\text { No. of } \\
\text { cows } \\
\text { per } \\
\text { farm }\end{array}$ & $\begin{array}{l}\text { Small } \\
(<100)\end{array}$ & $\begin{array}{l}\text { Medium (100- } \\
599)\end{array}$ & $\begin{array}{l}\text { Large } \\
(>599)\end{array}$ & $\begin{array}{l}\text { Grazin } \\
\mathrm{g}\end{array}$ & $\begin{array}{l}\text { Semi- } \\
\text { zero } \\
\text { grazing } \\
*\end{array}$ & $\begin{array}{l}\text { zero } \\
\text { grazing }\end{array}$ \\
\hline $\begin{array}{l}\text { SPE } \\
\text { Control }\end{array}$ & 11 & 4.4 & $10(91 \%)$ & $1(9 \%)$ & $0(0 \%)$ & $1(9 \%)$ & $0(0 \%)$ & $\begin{array}{l}10 \\
(91 \%)\end{array}$ \\
\hline SPE & 12 & 5.7 & $8(66 \%)$ & $4(33 \%)$ & $0(0 \%)$ & $0(0 \%)$ & $0(0 \%)$ & $\begin{array}{l}12 \\
(100 \%)\end{array}$ \\
\hline $\begin{array}{l}\text { Maize } \\
\text { train } \\
\text { Control }\end{array}$ & 11 & 22.2 & $0(0 \%)$ & $10(91 \%)$ & $1(9 \%)$ & $0(0 \%)$ & $\begin{array}{l}5 \\
(45 \%)\end{array}$ & $\begin{array}{l}6 \\
(55 \%)\end{array}$ \\
\hline $\begin{array}{l}\text { Maize } \\
\text { train }\end{array}$ & 12 & 26.7 & $0(0 \%)$ & $11(92 \%)$ & $1(8 \%)$ & $0(0 \%)$ & $\begin{array}{l}6 \\
(50 \%)\end{array}$ & $\begin{array}{l}6 \\
(50 \%)\end{array}$ \\
\hline
\end{tabular}

*Semi-zero grazing system: Where animals are allowed to graze only during certain times of the day or year and are confined for the rest of the time.

Table 4 shows that there was a balance allocation of the number of farms in intervention and control groups. There was also a comparable distribution of the farms into farm size categories and production systems. However, although the average number of mature cows per farm was 
slightly higher in the intervention groups compared to their controls, it was not significantly different $(p<0.05)$. Other group attributes are presented in Figures $4 \& 5$ and Table 5 below.

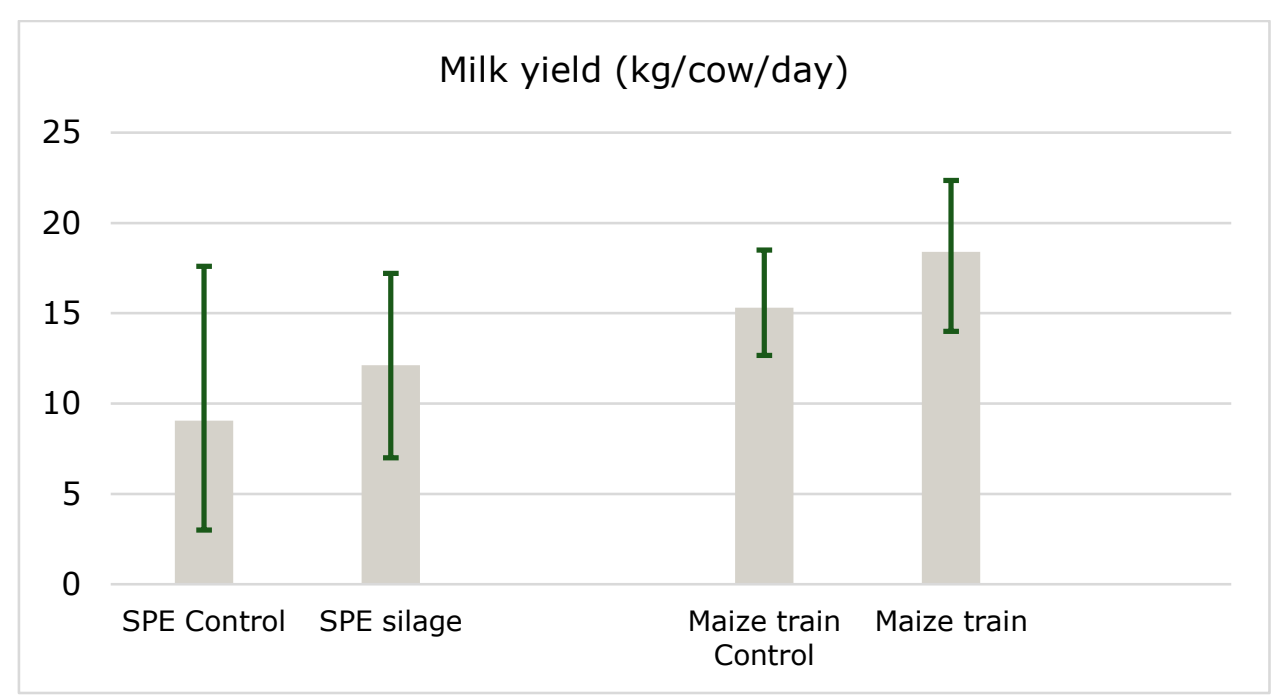

Figure 4 Average and minimum-maximum range for milk yield of fodder conservation interventions.

There was a significant difference (Figure 4) between the means for Maize train innovation $(M=18.39, S D=2.90)$ compared to its control $(M=15.32, S D=1.64) ; t(21)=3.10, p=0.005$. However, there was no significant difference between the means of SPE $(M=12.1, S D=3.4)$ innovation and its control $(M=9.1, S D=5.2) ; \mathrm{t}(21)=1.68, \mathrm{p}=0.108$. The milk yield range was smallest (less than 8 litres difference between the maximum and the minimum values) for the maize train group and its control. This is likely because of a more homogenous production system around Eldoret area where these large farms are based. The range between the maximum and minimum value was higher for the SPE control and the rationing groups because the smallholder farms in these groups are more diverse in their farm practices and in the range of inputs, hence the outputs too.

Though the daily milk income per cow (Figure 5) was higher in the intervention groups compared to their controls, it was only significantly different between the SPE $(M=370.9, S D=170.3)$ and its control $(M=211.2, S D=140.7) ; \mathrm{t}(21)=2.44, \mathrm{p}=0.024$. This is due to the slightly higher average milk yield per cow as shown in Figure 4, and a price advantage in the channels where SPE farmers sell their milk (Table 1 ). There was no significant difference $(p<0.05)$ between the intervention groups and their control in the total income per farm and the income per litre of milk. 


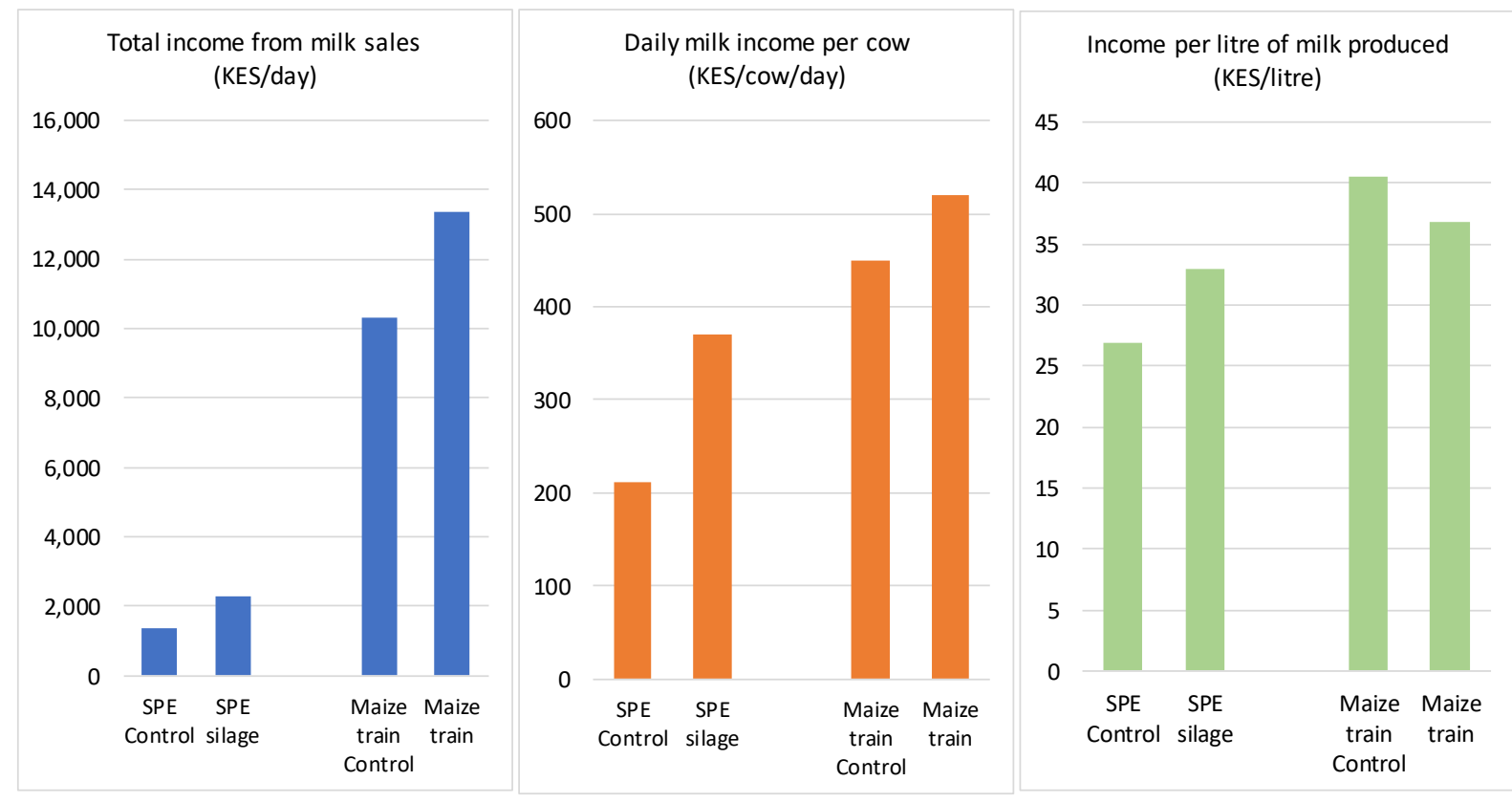

Figure 5 Average milk income a) per farm b) per cow per day and c) per litre of milk produced.

Table 5 Comparing the feed costs, milk income and Margin Above Feed Costs (MAFC) across interventions.

\begin{tabular}{|c|c|c|c|c|c|}
\hline $\begin{array}{l}\text { Interventi } \\
\text { on }\end{array}$ & $\begin{array}{l}\text { Feed } \\
\text { costs } \\
\text { (KES/t } \\
\text { DM) }\end{array}$ & $\begin{array}{l}\text { Feed cost } \\
(K E S / \text { cow } / d a \\
\text { y) }\end{array}$ & $\begin{array}{l}\text { Milk income } \\
\text { (KES/cow/da } \\
\text { y) }\end{array}$ & $\begin{array}{l}\text { MAFC } \\
\text { (KES/ } \\
\text { cow/day) }\end{array}$ & $\begin{array}{l}\text { Feed } \% \\
\text { income }\end{array}$ \\
\hline SPE Control & 26,145 & 384 & 489 & 105 & 74 \\
\hline SPE & 21,108 & 270 & 543 & 273 & 56 \\
\hline MT Control & 27,274 & 345 & 707 & 362 & 50 \\
\hline Maize train & 27,826 & 433 & 824 & 391 & 54 \\
\hline
\end{tabular}

$\overline{S P E}=$ Service Provider Enterprise $; M T=$ Maize train DM $=$ Dry matter $;$ MAFC = Margin Above Feed Costs

Table 5 shows that the Maize train group had the highest feed cost per ton, which contributed to the significantly higher feed cost per cow of this group, compared to its control $(p=0.03)$. On the other hand, though the milk income per cow was significantly higher in the Maize train group than its control $(p=0.02)$, there was no significant difference $(p<0.05)$ in the MAFC between the two groups. Meanwhile, the MAFC was significantly higher $(p=0.02)$ in the SPE group compared to its control. This was mainly due to the lower feed cost and slightly higher income per cow of the SPE group compared to its control.

In summary, the smallholder (SPE) farms which received SNV interventions had a higher income per cow than their control, while the larger (Maize train) farms had a higher milk yield per cow than their control, showing that SNV interventions had a positive impact on farms that adopted these innovations. 


\subsection{Should fodder conservation be accompanied by ration formulation?}

The figure (Figure 6) below shows the difference in total daily milk production per farm and daily milk yield between farms with no intervention, those only trained on fodder conservation and those that were trained on both fodder conservation and ration formulation.

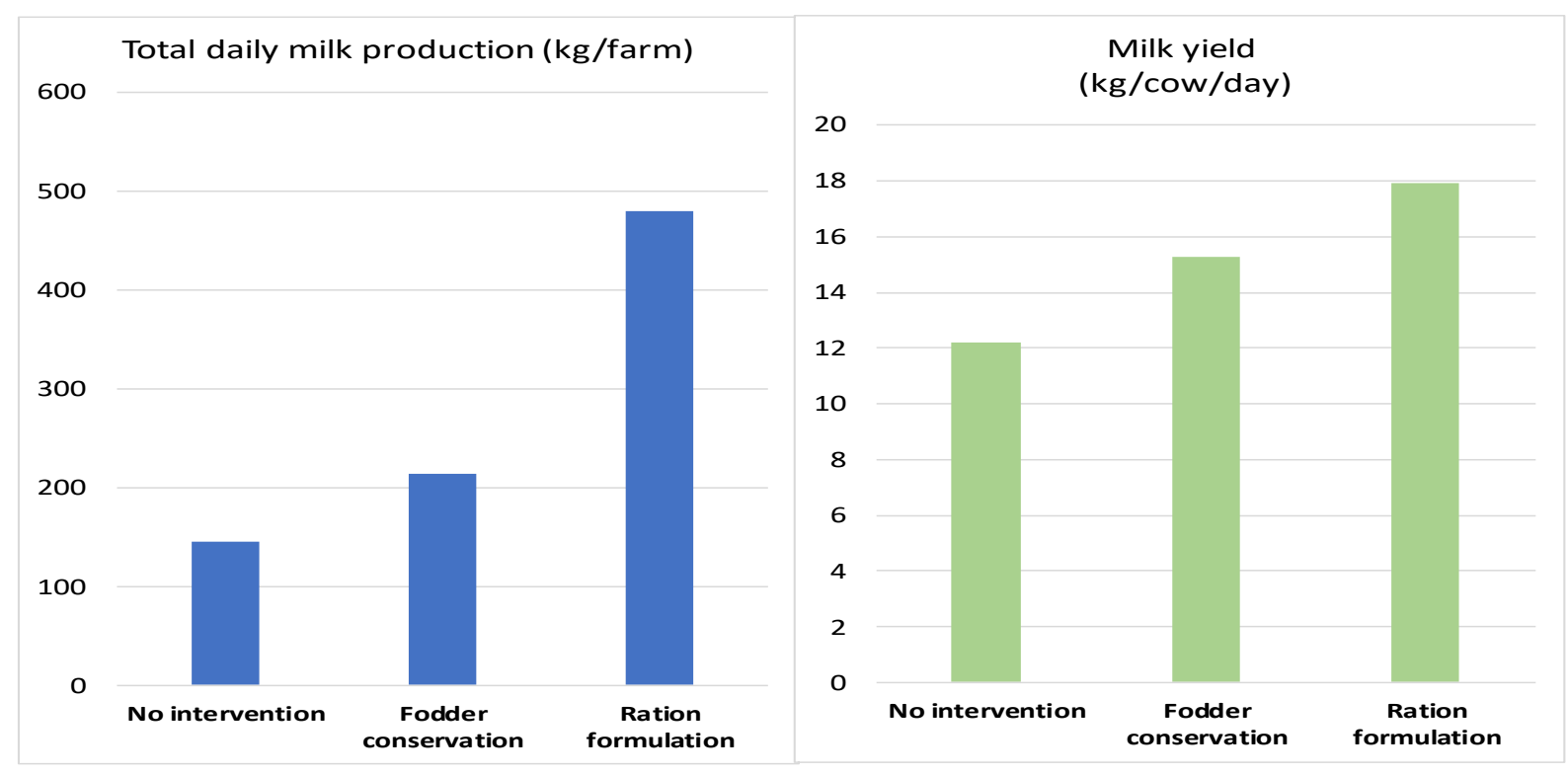

Figure 6 Milk production per farm and milk yield per cow among control and treatment farms.

The results show that both the total daily milk production per farm and daily milk yield per cow were higher in the farms where ration formulation was practiced followed by those with fodder conservation only (Figure 6). The average milk yield rose by about 3 litres per cow for farmers practicing fodder conservation compared to the control while farms formulating their ration had about 3 litres more milk per cow compared to those who only conserved fodder. These differences were significant $\left(F_{2,74}=7.96, p<0.001\right)$. This is because the farmers who conserved fodder could maintain feed supply over the year, while those who were trained in ration formulation also had the possibility to balance the ration and supplement for deficient nutrients in the diet.

As shown in Figure 7, the income per cow was significantly different between the controls and fodder conservation $(p=0.04)$, controls and ration formulation $(p=0.00)$, and fodder conservation and ration formulation $(p=0.04)$ groups. On the other hand, the income per litre of milk (calculated as total income from milk sales on the total volume of milk sold), did not differ significantly among the three groups $(p<0.05)$. A study by the FAO (FAO, 2012) confirms that imbalanced nutrition in livestock production is the major reason for low productivity. It further, elucidates that a balanced diet for the dairy animals improves on milk production and reduces the cost of production and greenhouse gas emissions. This increases milk productivity per farm and per cow thus the differences seen in Figures 6 and 7. 


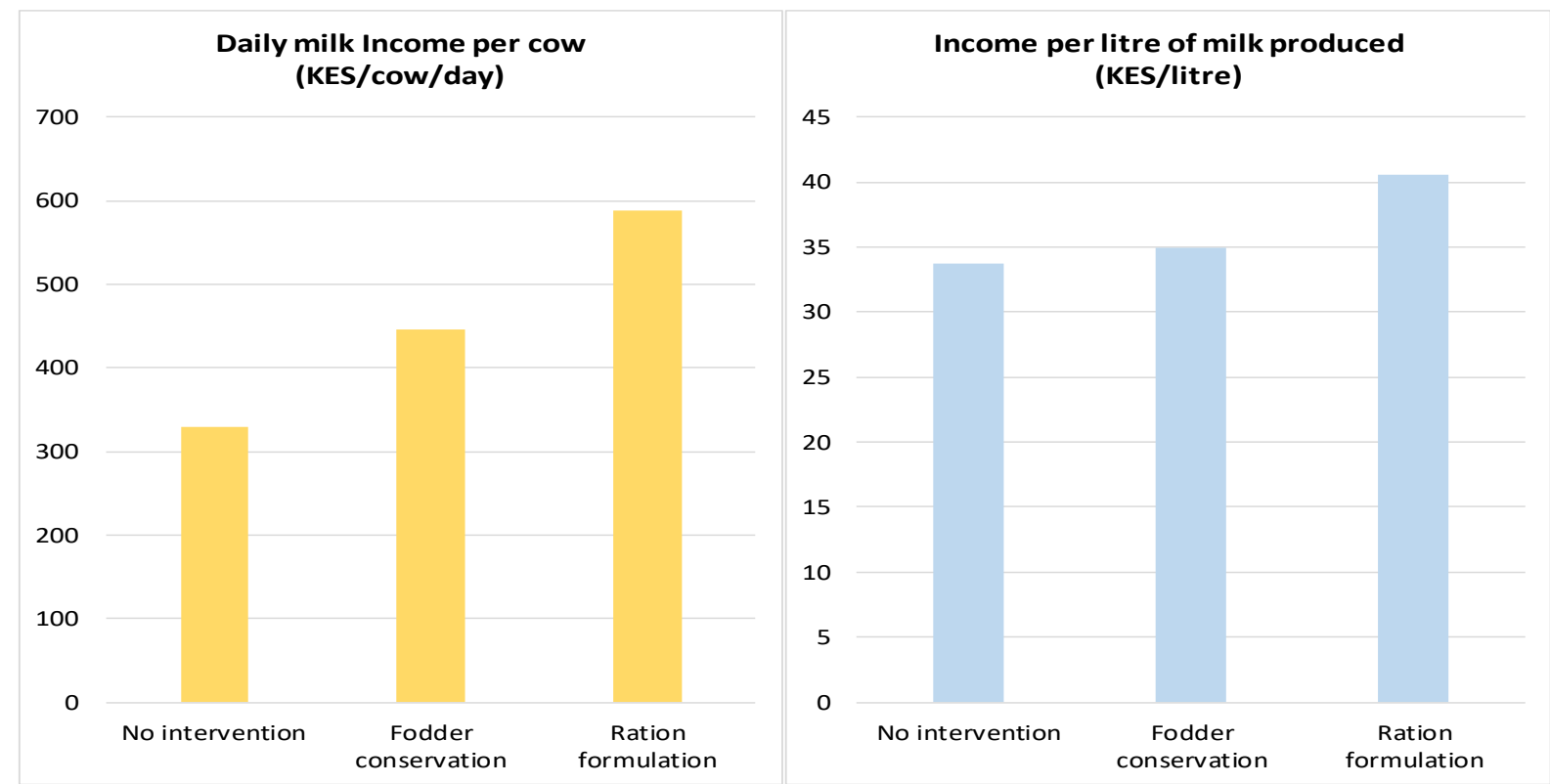

Figure 7 Daily milk income per cow and milk income per litre of milk produced.

Figure 8 shows the effectiveness of labour use in the study farms. The highest number of hours invested per cow per day was in the farms with no intervention. This is because most of these farms have few cows and the total labour input is divided by fewer cows compared to a larger farm with more cows. The farms with fodder conservation were the most effective in terms number of hours spent per cow. However, the means were not significantly different $(p<0.05)$. The number of litres of milk produced per hour of farm labour was significantly lower in the control group compared to the fodder conservation group $(p=0.005)$, and to the ration formulation group $(p=0.013)$. However, the fodder conservation group and the ration formulation group had a similar level in terms of milk produced per hour of labour.

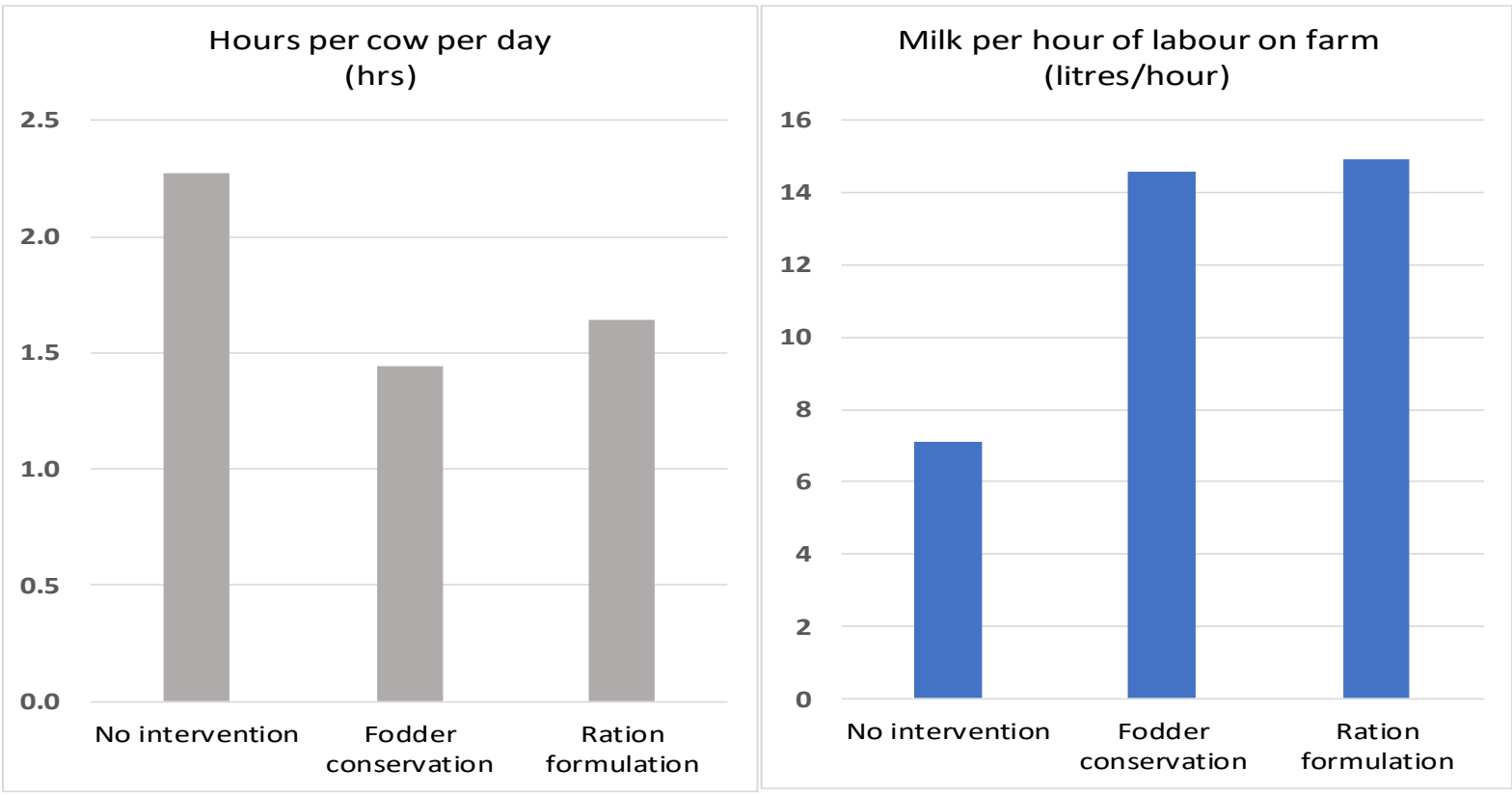

Figure 8 Labour productivity of dairy farms adopting different feed strategies.

In summary, the farms practicing ration formulation in addition to fodder conservation produce three litres more milk per cow daily, compared with farms practicing fodder conservation only, with the latter producing three litres more per cow compared to control farms. Further, the profitability of farms practicing conservation only was better in comparison with the control farms. 


\subsection{Should on-farm ration formulation trainings include regular (monthly) farm advisory visits?}

To answer this question, farms from the two groups: rationing without visit and rationing with monthly farm advisory visits were compared as shown in Table 6.

The results show that there was a significant difference between the mean values for milk yield per cow $(t(18)=2.94, p=0.009)$, feed cost $(t(18)=3.17, p=0.005)$, and milk income $(t(18)=3.04, p=0.007)$ between the farms practicing rationing with and without advisory visits. However, there was no significant difference in the margin above feed cost between the two groups due to the higher feed cost for the farms with rationing \& advisory visits. The disparity in the percentage of dry cows in the herds of the two groups contributed to a significant difference in milk yield per mature cow per year $(t(18)=3.38, p=0.003)$, indicating that the advisory visits might also have influenced herd management, affecting the overall performance of the farms.

An attempt made to estimate the additional value of farm advisory visits based on the results from Table 6 . Assuming that feed costs indicated in Table 6 are $60 \%$ of total costs (meaning total costs of 646 and 889 respectively in farms without and with advisory visits respectively), considering the total costs and milk income per cow of KES 654 and 950 respectively, an average difference in income per cow between farms with advisory visits and those without is 53 KES per day. This yields around KES 1,500 per cow per month and KES 15,000 for 10 cows in a month. Under these assumptions, a 10 -cow farm would be able to break-even if it pays KES 15,000 per month for formulation of rations combined with advisory services. The need for regular advisory services would however reduce over time, as observed in the field, except in farms where farm managers change. Therefore, farm owners might opt to stop the use of these services after some months. 
Table 6 Performance of study farms practicing rationing with and without monthly visits.

\begin{tabular}{lll} 
Item & $\begin{array}{l}\text { Rationing } \\
\text { advisory visit }\end{array}$ & $\begin{array}{l}\text { Rationing } \\
\text { advisory visit }\end{array}$ \\
*Milk yield (kg/lactating cow/day) & 14.6 & 20.6 \\
\hline$*$ Feed cost (KES/cow/day) & 387.5 & 533.3 \\
\hline$*$ Milk income (KES/cow/day) & 653.8 & 950.5 \\
\hline$*$ Margin above feed cost (KES/cow/day) & 266.3 & 417.1 \\
\hline & & 45.0 \\
\hline Income per litre (KES/litre) & 1.7 \\
\hline Hours spent per cow per day & 41.4 & 17.3 \\
\hline Milk per hour (litres/hr) & 1.2 & $15 \%$ \\
\hline Percentage of dry cows in herd & 19.7 & $6,227.7$ \\
\hline Milk yield (kg per mature cow per year) & $23 \%$ &
\end{tabular}

*Items calculated using Rumen8 tool

In summary, farm advisory visits in addition to the use of the Rumen8 software led to significantly higher milk yield and milk income compared to farms with ration formulation only. However, the labour efficiency was lower in the farms using this software probably due to more time required for preparing feeds and management.

\subsection{Do conservation and ration formulation strategies affect seasonality in production?}

The mean monthly variation in milk yield and milk production per farm were used to understand the effect of feed availability during different months as shown in Figure 9.

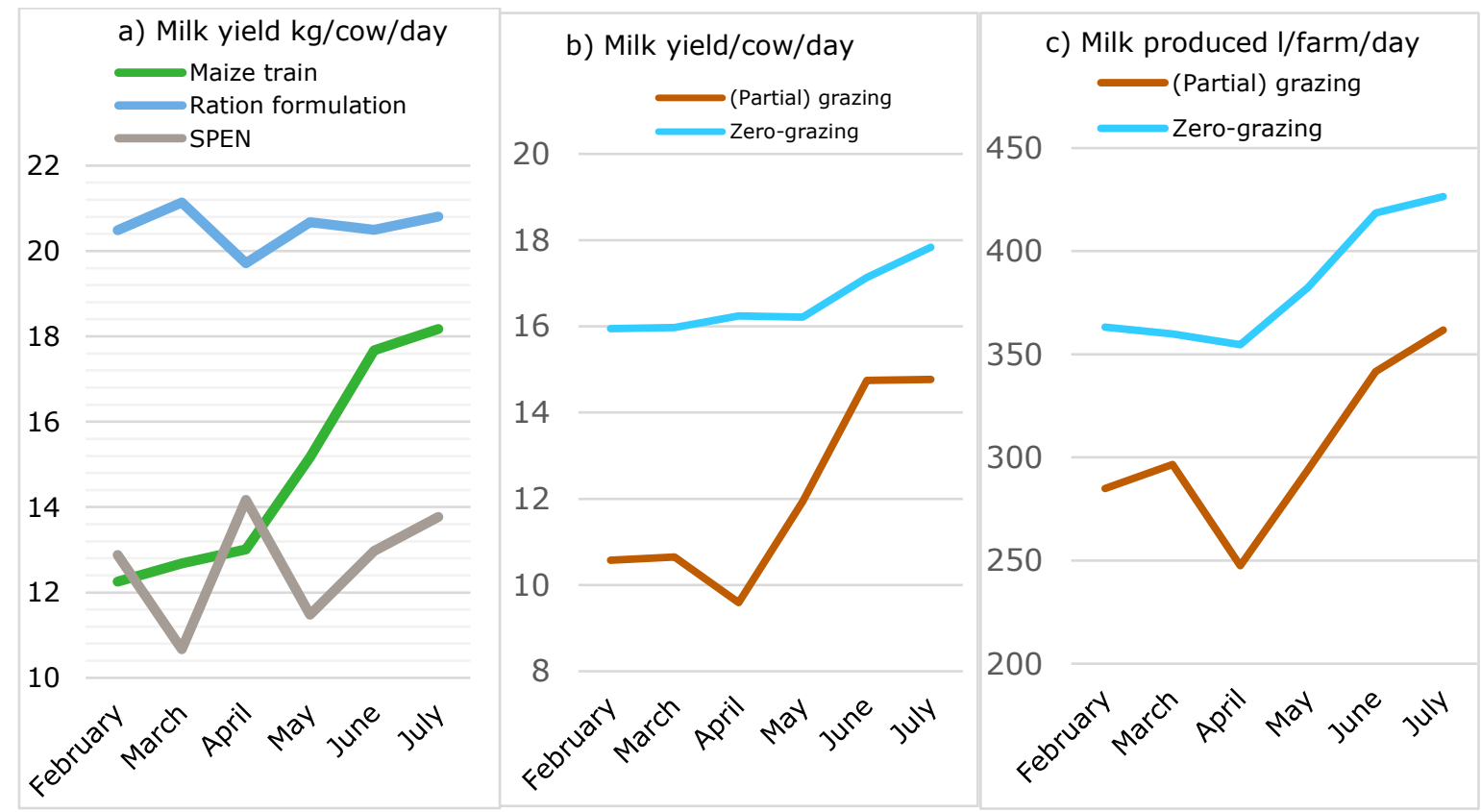

Figure 2 Monthly milk yields a) per cow per day between interventions b) per cow per day between farming systems and c) per farm per day between farming systems.

A trendline analysis shows that there was significant variation of milk yield for the Maize train farms $\left(R^{2}=0.91\right)$, but the monthly variation was not significant for the SPE and Ration formulation groups. Likewise, there was a variation in the milk yield per cow for both the partial zero grazing systems $\left(R^{2}=0.81\right)$ and the zero-grazing systems $\left(R^{2}=0.72\right)$. These results show 
that the SPE and Ration formulation groups did not show a significant seasonality in production and therefore could have succeeded in maintaining a more stable availability of fodder over the seasons, which was not the case with the maize train farms. Since the Maize train farms are in the potential maize belt zone, maize silage and maize stovers are more available after the rainy season, which affects productivity of cows (Wambugu et al., 2011).

Both the (partial) grazing and zero grazing systems experienced seasonal variations in milk production, though this was more severe in the (partial) grazing systems than in the zero grazing systems. Partial grazing farms depend much on the rains for growth and availability of pastures. During the rainy season, pastures are available and the dairy cows get enough thus increasing their production.

Unfortunately, it was not possible to compare the monthly trends between the interventions and their control, since data from the controls were only collected for one month (July). Also, data were not consistently available for all intervention farms for all months, rendering the seasonal comparison challenging.

In summary, monthly milk yield per cow was more seasonal in the Maize train farms than in the farms practicing ration formulation, and was also more seasonal in (partial) grazing systems than in zero-grazing systems. However, the available data was insufficient to do a proper analysis of the effect of the interventions on seasonality.

\subsection{Do forage management interventions influence Nitrogen Use Efficiency of dairy farms?}

Nitrogen intake, nitrogen output and Nitrogen Use Efficiency (NUE) per cow are shown in Figure 10 .

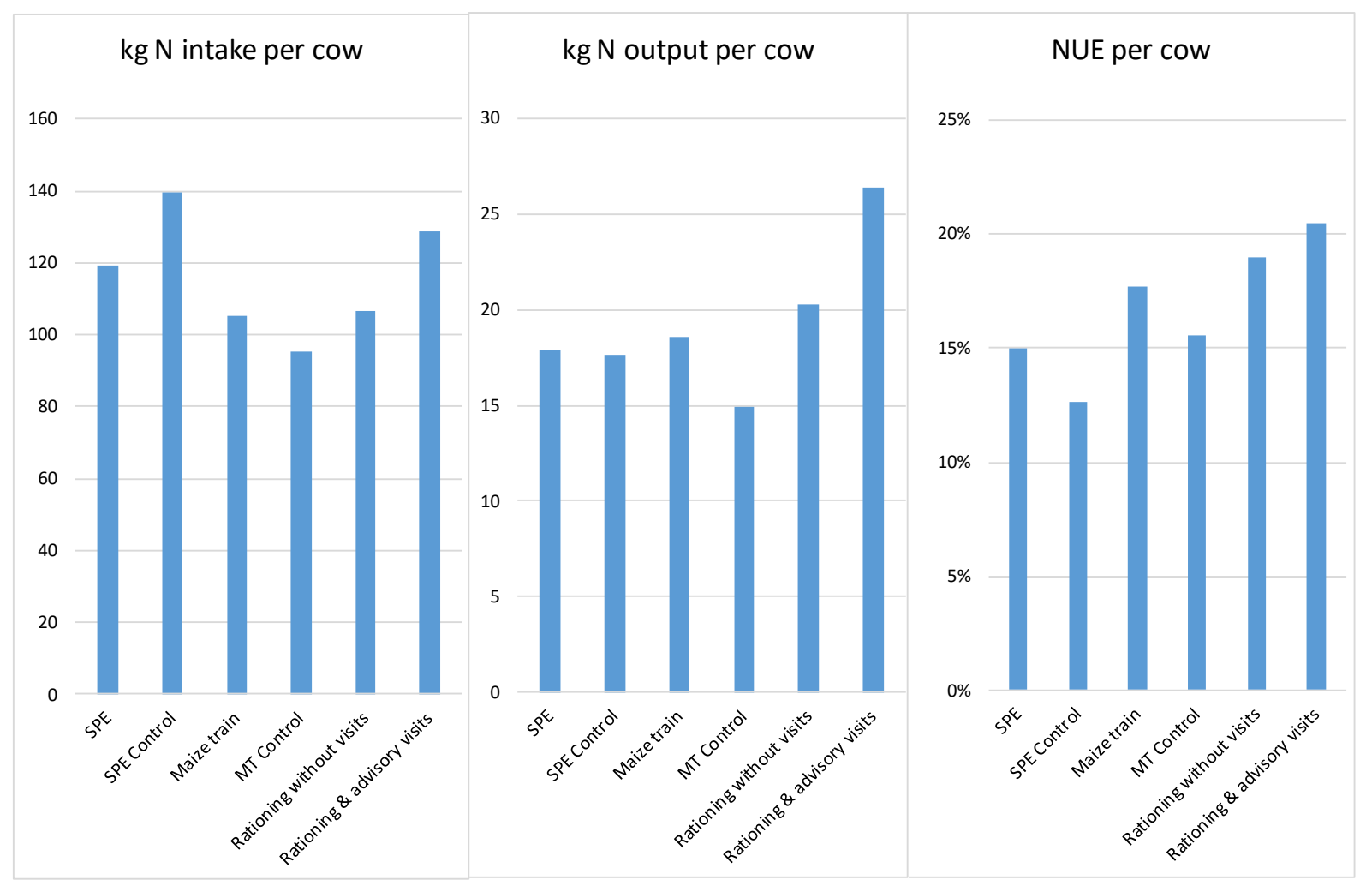

Figure 3 Nitrogen intake, nitrogen output and Nitrogen Use Efficiency (NUE) per cow.

The differences in NUE between interventions was minimal. SPE control had the lowest NUE. This is because being smallholder farms, SPE control farmers often fed their animals with large 
amounts of straw and poor quality hay with a high dry matter content. The SPE intervention farms, on the other hand, were likely to feed less of straw because they also fed silage.

The difference in output and input ratios reflect the varying nature of feed conversion and management (Oenema, 2006). Dairy production systems are expected to contribute to the growing demand of human-edible protein while at the same time facing the challenges of environmental impacts, e.g., GHG emissions (Özkan Gülzari et al., 2017), climate change (Özkan et al., 2015), as well as the accumulation of nitrogen ( $N$ ) and phosphorus (P) in the ground and surface water (Oenema, 2006). Therefore, there is a potential for future studies assessing the whole-farm GHG emissions of these interventions, given the unique management practices (e.g. manure and soil, in particular) associated with each intervention strategy. It should be noted that the impact of manure utilisation and soil mining were excluded in this study due mainly to a lack of resources and time. Therefore, it is recommended that a future study investigates the extent to which manure collection and utilisation, as well as soil mining affect the NUE of these interventions. It is expected that the impact of fertiliser on current figures would have been small in the SPE farms and larger in the ration balancing farms, but without a comprehensive assessment, it is difficult to draw conclusions. 


\section{Conclusions}

We studied the impact of feed conservation and ration formulation on the economic performance and NUE of dairy farms in central, eastern and rift valley regions of Kenya where the Dutchfunded KMDP fodder innovations project has been going on since March 2012.

The results show that smallholder (SPE) farms which received SNV interventions had a higher income per cow than their control, while the larger (Maize train) farms had a higher milk yield per cow than their control, showing that KMDP fodder conservation interventions had a positive impact on farms that adopted these innovations.

The benefits from fodder conservation increased when fodder conservation was combined with ration formulation. Farms practicing ration formulation in addition to fodder conservation produced three litres more milk per cow daily, compared with farms practicing fodder conservation only, with the latter producing three litres more milk per cow daily compared to control farms. Further, the profitability of farms practicing conservation only was better in comparison with control farms.

Farms formulating feed rations using the Rumen8 software in combination with monthly advisory visits had a significantly higher milk yield and milk income per cow compared to farms formulating feed rations without the Rumen8 software and without monthly advise. However, the labour efficiency was lower in the farms formulating feed rations combined with monthly advisory visits, probably due to more time required in preparing feeds and farm management. We suggest that better feed planning could further reduce the feed cost. The differences in terms of NUE between interventions were small.

We recommend that farmers should adopt fodder conservation measures in combination to ration formulation in order to increase their profitability. Ration formulation advisory programs should include follow-up visits for a longer duration to enable farm managers better understand the concepts involved in formulation. Finally, unique management structures of each intervention require a more comprehensive assessment of NUE, including soil mining and management of manure, e.g., collection and utilisation on the field. 


\section{$5 \quad$ References}

Alqaisi, O., Hemme, T., Latacz-Lohmann, U., and Susenbeth, A. (2014). Evaluation of food industry by-products as feed in semi-arid dairy farming systems: the case of Jordan. Sustain. Sci. 9, 361-377. doi:10.1007/s11625-013-0240-6.

AOAC (1995). Official methods of analysis of AOAC International. Arlington, Va. AOAC Intl. pv.

Braamhaar, D. (2019). A pilot about integration of diet formulation software in dairy farm coaching in Kenya. To improve milk yield and margin above feed costs, and to reduce enteric methane emission intensity.

Brouwer, F. (1998). Nitrogen balances at farm level as a tool to monitor effects of agrienvironmental policy. Nutr. Cycl. Agroecosystems 52, 303-308.

Dalgaard, T., Halberg, N., and Kristensen, I. S. (1998). Can organic farming help to reduce Nlosses? Experiences from Denmark. Nutr. Cycl. Agroecosystems 52, 277-287.

Eckard, R. J., Grainger, C., and de Klein, C. A. M. (2010). Options for the abatement of methane and nitrous oxide from ruminant production: A review. Livest. Sci. doi: 10.1016/j.livsci.2010.02.010.

FAO (2012). Balanced Feeding for Improving Livestock Productivity.

Gerber, P.J.; Steinfeld, H.; Henderson, B.; Mottet, A.; Opio, C.; Dijkman, J.; Falcucci, A. ; Tempio, G. (2013). Tackling climate change through livestock - A global assessment of emissions and mitigation opportunities, Food and Agriculture Organization of the United Nations (FAO):

Gerber, P. J., Uwizeye, A., Schulte, R. P. O., Opio, C. I., and de Boer, I. J. M. (2014). Nutrient use efficiency: a valuable approach to benchmark the sustainability of nutrient use in global livestock production? Curr. Opin. Environ. Sustain. 9, 122-130.

Godinot, O., Carof, M., Vertès, F., and Leterme, P. (2014). SyNE: an improved indicator to assess nitrogen efficiency of farming systems. Agric. Syst. 127, 41-52.

Haworth, G. M., Tranter, W. P., Chuck, J. N., Cheng, Z., and Wathes, D. C. (2008). Relationships between age at first calving and first lactation milk yield, and lifetime productivity and longevity in dairy cows. Vet. Rec. doi:10.1136/vr.162.20.643.

Kilelu, C. W., Koge, J., Kabuga, C., and Lee, J. Van Der (2017). Performance of emerging dairy services agri- enterprises: a case study of youth-led service provider enterprises (SPE) Performance of emerging dairy services agri-enterprises : a case study of youth-led service provider enterprises. 3R Kenya Proj. Pract. Br. 002. Wageningen Livest. Res.

MoALF (2010). Kenya National Dairy Master Plan - A situational Analysis of the Dairy Sub sector, Volume I. Situational Analysis. Available at: http://www.kdb.go.ke/download/kenyanational-dairy-master-plan-vol-i-situational-analysis/ [Accessed August 7, 2019].

Mungube, E., Njarui, D., Maichomo, M., Olum, M., Ndirangu, P., Kabirizi, J., et al. (2019). Reproductive performance indicators of dairy cattle in selected small-scale dairy farms in semi-arid Eastern Kenya. Livest. Res. Rural Dev. 31.

Ndambi, A., Zijlstra, J., Ngigi, M., Van der Lee, J., and Kilelu, C. (2017). Calculating on-farm cost of milk production in KenyaAssessing the suitability of five methodsbeing used in Kenya. Wageningen Available at: https://edepot.wur.nl/459982.

Njarui, D., Gichangi, E., Gatheru, M., Nyambati, E., Ondiko, C., MN, N., et al. (2016). A comparative analysis of livestock farming in smallholder mixed crop-livestock systems in Kenya: 1. Livestock inventory and management. Livest. Res. Rural Dev. 28. Available at: http://www.Irrd.org/Irrd28/4/njar28066.html.

Oenema, O. (2006). Nitrogen budgets and losses in livestock systems. Int. Congr. Ser. 1293, 262-271. doi:https://doi.org/10.1016/j.ics.2006.02.040.

Oenema, O., and Tamminga, S. (2005). Nitrogen in global animal production and management options for improving nitrogen use efficiency. Sci. China Ser. C Life Sci. 48, 871-887. 
Olwande, J., Smale, M., Mathenge, M. K., Place, F., and Mithöfer, D. (2015). Agricultural marketing by smallholders in Kenya: A comparison of maize, kale and dairy. Food Policy 52, 22-32. doi:10.1016/j.foodpol.2015.02.002.

Özkan Gülzari, Ş., Åby, B. A., Persson, T., Höglind, M., and Mittenzwei, K. (2017). Combining models to estimate the impacts of future climate scenarios on feed supply, greenhouse gas emissions and economic performance on dairy farms in Norway. Agric. Syst. 157, 157-169. doi:https://doi.org/10.1016/j.agsy.2017.07.004.

Özkan, Ş., Hill, J., and Cullen, B. (2015). Effect of climate variability on pasture-based dairy feeding systems in south-east Australia. Anim. Prod. Sci. 55, 1106-1116. doi:http://dx.doi.org/10.1071/AN14493.

Rademaker, C. J., Omedo Bebe, B., van der Lee, J., Kilelu, C., and Tonui, C. (2016). Sustainable growth of the Kenyan dairy sector: a quick scan of robustness, reliability and resilience. doi: $10.18174 / 391018$.

Snijders, P. J. ., Wouters, B. ., and Kariuki, J. . (2011). Effect of cutting management and nitrogen supply on yield and quality of Napier grass (Pennisetum purpureum).

Wambugu, S., Kirimi, L., and Opiyo, J. (2011). Productivity Trends and Performance of Dairy Farming in Kenya. Tegemeo working paper no 43. Tegemeo Inst. Agric. Policy Dev. doi:WPS 43/2011.

WATANABE, K., LEWIS, B., MLEWAH, T. B., and TETSUKA, M. (2017). Age at First Calving and Factors Influencing it in Dairy Heifers Kept by Smallholder Farmers in Southern Malawi. Japan Agric. Res. Q. JARQ 51, 357-362. doi:10.6090/jarq.51.357. 


\section{Appendix 1 Feed ingredients and their nutritive value as used in NUE calculations}

\begin{tabular}{|c|c|c|}
\hline Feed ingredient & DM $(\mathrm{g} / \mathrm{kg})$ & $\mathrm{CP}(\mathrm{g} / \mathrm{kg} \mathrm{DM})$ \\
\hline Banana stems & 103 & 60 \\
\hline Barley straw & 905 & 39 \\
\hline Bean straw & 902 & 71 \\
\hline Boma Rhodes grass & 272 & 95 \\
\hline Bracharia & 252 & 12.9 \\
\hline Cabbage & 105 & 181 \\
\hline Dairy meal & 900 & 150 \\
\hline Grass silage & 237 & 77 \\
\hline Kikuyu grass & 232 & 142 \\
\hline Lucerne & 245 & 200 \\
\hline Maize germ & 894 & 127 \\
\hline Maize grain & 886 & 93 \\
\hline Maize silage & 262 & 65 \\
\hline Maize stover & 895 & 52 \\
\hline Millet stover & 905 & 39 \\
\hline Nandi setaria & 211 & 72 \\
\hline Napier grass & 184 & 88 \\
\hline Oats straw & 909 & 50 \\
\hline Poultry waste & 877 & 197 \\
\hline Rice straw & 881 & 46 \\
\hline Sorghum fresh & 244 & 78 \\
\hline Sudan grass & 211 & 72 \\
\hline Sweet potato vines & 120 & 165 \\
\hline Wheat bran & 883 & 165 \\
\hline Wheat pollard & 890 & 154 \\
\hline Wheat straw & 898 & 37 \\
\hline Whole green maize chops & 251 & 61 \\
\hline
\end{tabular}

Source: Rumen8 tool 

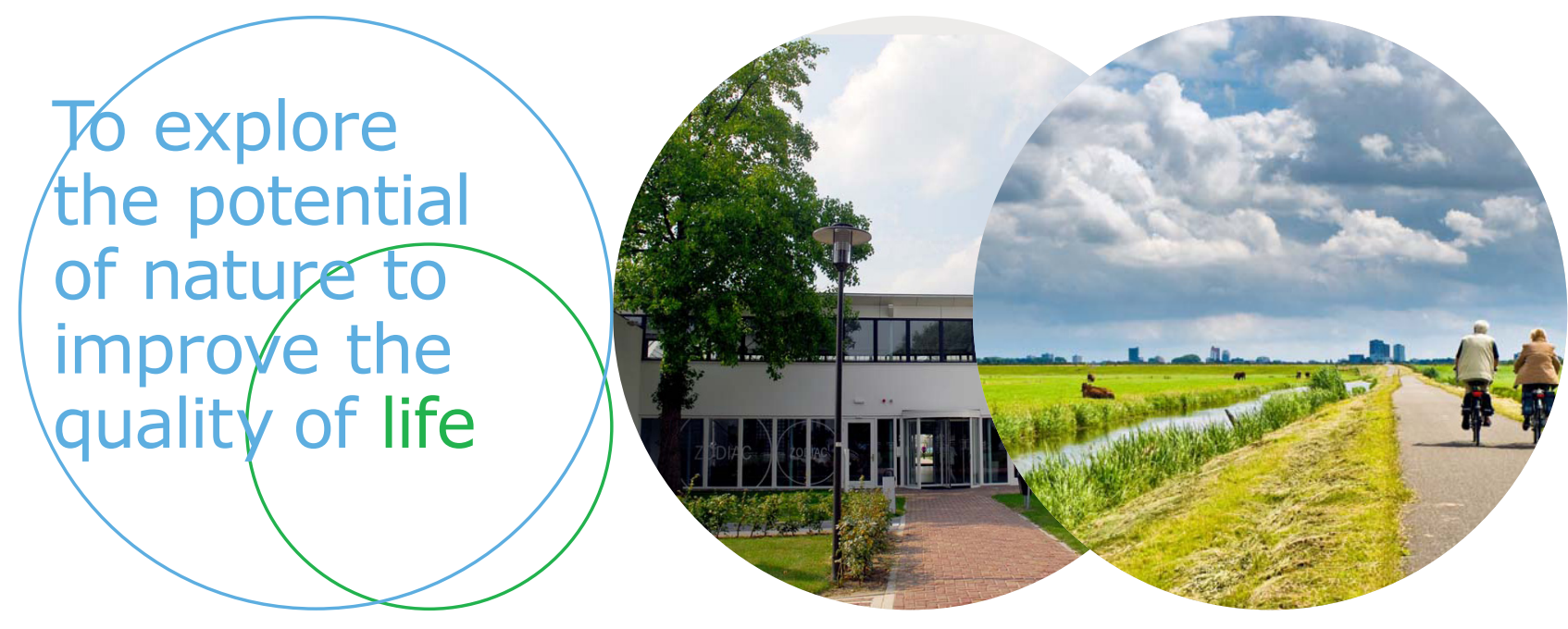

Wageningen Livestock Research P.O. Box 338

6700 AH Wageningen

The Netherlands

$\mathrm{T}+31(0) 317483953$

E info.livestockresearch@wur.nl

www.wur.nl/livestock-research

Wageningen Livestock Research creates science based solutions for a sustainable and profitable livestock sector. Together with our clients, we integrate scientific knowledge and practical experience to develop livestock concepts for future generations.

Wageningen Livestock Research is part of Wageningen University \& Research. Together we work on the mission: 'To explore the potential of nature to improve the quality of life'. A staff of 6,500 and 10,000 students from over 100 countries are working worldwide in the domain of healthy food and living environment for governments and the business community-at-large. The strength of Wageningen University \& Research lies in its ability to join the forces of specialised research institutes and the university. It also lies in the combined efforts of the various fields of natural and social sciences. This union of expertise leads to scientific breakthroughs that can quickly be put into practice and be incorporated into education. This is the Wageningen Approach. 